\title{
Article \\ Common Bean Yield and Zinc Use Efficiency in Association with Diazotrophic Bacteria Co-Inoculations
}

\author{
Arshad Jalal ${ }^{1}$, Fernando Shintate Galindo ${ }^{2}$, Eduardo Henrique Marcandalli Boleta ${ }^{1}$, \\ Carlos Eduardo da Silva Oliveira ${ }^{1}\left(\mathbb{D}\right.$, André Rodrigues dos Reis ${ }^{3} \mathbb{D}^{\circ}$, Thiago Assis Rodrigues Nogueira ${ }^{1}(\mathbb{C}$, \\ Mário João Moretti Neto ${ }^{1}$, Emariane Satin Mortinho ${ }^{1}$, Guilherme Carlos Fernandes ${ }^{1}$ \\ and Marcelo Carvalho Minhoto Teixeira Filho ${ }^{1, *}$
}

Citation: Jalal, A.; Galindo, F.S.; Boleta, E.H.M.; Oliveira, C.E.d.S.; Reis, A.R.d.; Nogueira, T.A.R.; Moretti Neto, M.J.; Mortinho, E.S.; Fernandes, G.C.; Teixeira Filho, M.C.M. Common Bean Yield and Zinc Use Efficiency in Association with Diazotrophic Bacteria Co-Inoculations. Agronomy 2021, 11, 959. https://doi.org/10.3390/ agronomy11050959

Academic Editor: Borjana Arsova

Received: 12 April 2021

Accepted: 7 May 2021

Published: 12 May 2021

Publisher's Note: MDPI stays neutral with regard to jurisdictional claims in published maps and institutional affiliations.

Copyright: (c) 2021 by the authors. Licensee MDPI, Basel, Switzerland. This article is an open access article distributed under the terms and conditions of the Creative Commons Attribution (CC BY) license (https:/ / creativecommons.org/licenses/by/ $4.0 /)$.
1 Department of Plant Protection, Rural Engineering and Soils (DEFERS), São Paulo State University (UNESP), Ilha Solteira 15385-000, SP, Brazil; arshad.jalal@unesp.br (A.J.); eduardomarcandalli7@gmail.com (E.H.M.B.); ces.oliveira@unesp.br (C.E.d.S.O.); tar.nogueira@unesp.br (T.A.R.N.); mario.moretti@unesp.br (M.J.M.N.); emariane.satin@unesp.br (E.S.M.); guilherme.carlos.fernandes@gmail.com (G.C.F.)

2 Center for Nuclear Energy in Agriculture (CENA), University of São Paulo (USP), Piracicaba 13416-000, SP, Brazil; fs.galindo@yahoo.com.br

3 School of Sciences and Engineering, São Paulo State University (UNESP), Tupã 17602-496, SP, Brazil; andre.reis@unesp.br

* Correspondence: mcm.teixeira-filho@unesp.br

\begin{abstract}
Enrichment of staple food with zinc ( $\mathrm{Zn})$ along with solubilizing bacteria is a sustainable and practical approach to overcome $\mathrm{Zn}$ malnutrition in human beings by improving plant nutrition, nutrient use efficiency, and productivity. Common bean (Phaseolus vulgaris L.) is one of a staple food of global population and has a prospective role in agronomic $\mathrm{Zn}$ biofortification. In this context, we evaluated the effect of diazotrophic bacterial co-inoculations (No inoculation, Rhizobium tropici, R. tropici + Azospirillum brasilense, $R$. tropici + Bacillus subtilis, R. tropici + Pseudomonas fluorescens, $R$. tropici + A. brasilense $+B$. subtilis, and $R$. tropici + A. brasilense + P. fluorescens) in association with soil $\mathrm{Zn}$ application (without and with $8 \mathrm{~kg} \mathrm{Zn} \mathrm{ha}^{-1}$ ) on $\mathrm{Zn}$ nutrition, growth, yield, and $\mathrm{Zn}$ use efficiencies in common bean in the 2019 and 2020 crop seasons. Soil Zn application in combination with $R$. tropici + B. subtilis improved $\mathrm{Zn}$ accumulation in shoot and grains with greater shoot dry matter, grain yield, and estimated Zn intake. Zinc use efficiency, recovery, and utilization were also increased with co-inoculation of $R$. tropici $+B$. subtilis, whereas agro-physiological efficiency was increased with triple co-inoculation of $R$. tropici $+A$. brasilense $+P$. fluorescens. Therefore, co-inoculation of R. tropici + B. subtilis in association with $\mathrm{Zn}$ application is recommended for biofortification and higher $\mathrm{Zn}$ use efficiencies in common bean in the tropical savannah of Brazil.
\end{abstract}

Keywords: Phaseolus vulgaris L.; diazotrophic bacteria; zinc fertilization; Zn uptake; Zn biofortification

\section{Introduction}

Common bean (Phaseolus vulgaris L.) originated in central Mexico and is now grown globally, especially in Central and South America [1]. Beans have imperative traditional, historical, and nutritional profiles (proteins, amino acid, and minerals, as well as antioxidants and polyphenols) that fulfill the nutritional needs of human diet in many regions of the world as a staple food source [2,3]. The global annual average bean production is about 26.5 million tons [4]. The mean production of beans in Brazil has increased by 3.15 million tons in the preceding 20 years, being adjusted to Brazil demand [5]. Legumes improve soil fertility by fixing nitrogen $(\mathrm{N})$, enhancing microbial activity, and decreasing dependency on mineral fertilizers, which helps to promote a sustainable environment and production [6].

Zinc $(\mathrm{Zn})$ is one of the most important micronutrients for all living organisms [7], including plants, humans, and micro-flora [8] and is required throughout their life cycles in small quantities to orchestrate a complete array of physiological functions [9]. Zinc deficiency has frequently been reported in tropical crops [10], concurrently being declared as 
"hunger of the day", with several health issues [11], especially in developing countries [12]. Zinc deficiency affects almost $17.3 \%$ of the global population and $30 \%$ of South Asian countries [13], and therefore affects 2 billion people within the global population, and it is ranked as the fifth highest health risk factor in developing countries [14,15]. The inadequate dietary status of $\mathrm{Zn}$ is anti-proportional to human health and leads to several diseases [16], including immune deficiency syndrome, pneumonia, memory disorder, cancer, respiratory and cardiovascular disorder, and diarrhea in humans $[17,18]$. In the current scenario, it is interesting that Zn deficiency may be one of the predisposing factors for the infection and progression of COVID-19 [19].

Zinc deficiency in crop plants is an alarming concern and is the most effective micronutrient limiter in legume yields. Zinc plays a critical role in several plant physiological processes, including protein synthesis [20], energy production, maintenance of membrane integrity, and cell growth and multiplication [21]. Zinc also has a role in different photosynthetic and enzymatic activities such as peptidases, dehydrogenases, phosphohydrolases, and pollen fertility $[22,23]$. It is therefore important to combat $\mathrm{Zn}$ deficiency in soil, plants, and most importantly, in human beings [24,25]. Soil $\mathrm{Zn}$ application is the most practiced strategy in field crops to improve yield and grain Zn concentration [26]. The deficiency of Zn cannot be treated solely with Zn application for better crop establishment, productivity, and $\mathrm{Zn}$ use efficiency, especially in tropical regions, due to complexation with carbonates and oxides [27]. Therefore, new alternatives and sustainable strategies need to be adapted for better nutrient replenishment and productivity with higher Zn use efficiency (ZnUE).

Nutrients enriched plant rhizosphere environments significantly stimulate several ecological processes such as decomposition of organic matter, homeostasis, and nutrient cycling to reduce crop dependency on synthetic fertilizers to support sustainable and stable ecosystems [28]. Plant growth-promoting bacteria (PGPBs) or diazotrophic bacteria adapt several direct and indirect mechanisms to improve plant growth [29]. They improve nutrient availability by playing a role in biological nitrogen fixation (BNF), nutrient solubilization, and enzymes synthesis through direct mechanisms [29-31] while inhibiting pathogen infestation by producing siderophores and antibiotics [32]. Zinc solubilizing bacteria could be applied in one or more of the above mentioned mechanisms to increase Zn solubility through production of organic and inorganic acids and several chelators [33]. A diverse range of bacteria including species of Rhizobium, Pseudomonas, Azospirillum, Azotobacter, Bacillus, Enterobacter, Acinetobacter, and many others may solubilize or tolerate $\mathrm{Zn}$ and plant growth promoters [23,34,35].

The effects $\mathrm{Zn}$ biofortification of the interaction of diazotrophic bacteria in co-inoculation with soil applied $\mathrm{Zn}$ is lacking in the literature. There is a research gap on the association of diazotrophic bacterial co-inoculation and $\mathrm{Zn}$ fertilization on $\mathrm{Zn}$ nutrition, $\mathrm{ZnUE}$, and yields of common bean. It is necessary to determine such strategies to improve the $\mathrm{Zn}$ nutritional quality of common bean to increase the dietary intake of the population. Therefore, the hypothesis of this study was that there may be a synergetic association of different diazotrophic bacteria with soil Zn application on Zn availability on plant and soil, ZnUE, yield, and intake of fortified common bean in the tropical savannah of Brazil. The objectives of the study were to evaluate the effect of soil $\mathrm{Zn}$ application in combination with seed inoculation of different diazotrophic bacteria on common bean growth and yield. Additionally, the effect of co-inoculations and $\mathrm{Zn}$ fertilization on $\mathrm{Zn}$ accumulation in plant shoot and grains, $\mathrm{Zn}$ intake, and $\mathrm{Zn}$ use efficiencies for sustainable biofortification in the tropical savannah of Brazil.

\section{Materials and Methods}

\subsection{Experimental Area and Location}

A field experiment on common bean was performed during two consecutive cropping years (2019 and 2020) at the research farm of the School of Engineering (UNESP) at the geographical coordinates $20^{\circ} 22^{\prime} \mathrm{S}, 51^{\circ} 22^{\prime} \mathrm{W}$, and $335 \mathrm{~m}$ altitude (Figure 1), located in Mato Grosso do Sul, Brazil. The soil is classified as Rhodic Haplustox with clay texture [36]. 
The experimental site has been used for the cultivation of an annual crop (cereals and legumes) for more than 28 years, the last 12 being under no tillage [37]. The climate of the experimental area is classified as Aw according to Köppen classification, and the data of both cropping seasons are summarized in Figure 2.

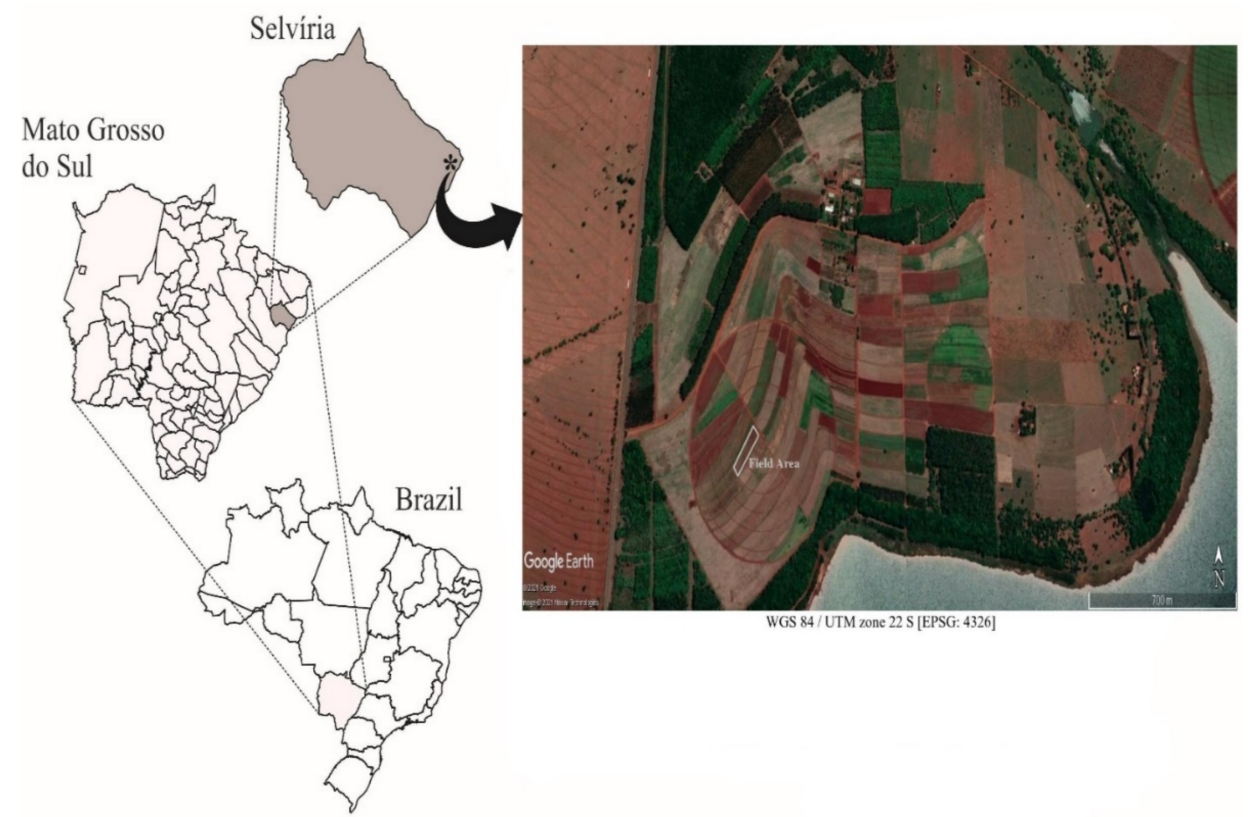

Figure 1. Location of the experimental area at the Research and Extension Farm, UNESP-Ilha Solteira Campus, at Selvíria-Mato Grosso do Sul state, Brazil $\left(20^{\circ} 22^{\prime} \mathrm{S}, 51^{\circ} 22^{\prime} \mathrm{W}\right.$, altitude of $\left.335 \mathrm{~m}\right)$ in 2019 and 2020 crop seasons. The map was created by using geographic information system (QGIS) software and the Google Earth program. The QGIS Development Team (2021). Open Source Geospatial Foundation project. http:/ / qgis.osgeo.org. Accessed on: 9 March 2021. Projection System WGS 84/UTM 200DC [EPSG: 4326]. This image was taken from the Google Earth program, Google Company (2021). Map data: Google, Maxar Technologies.

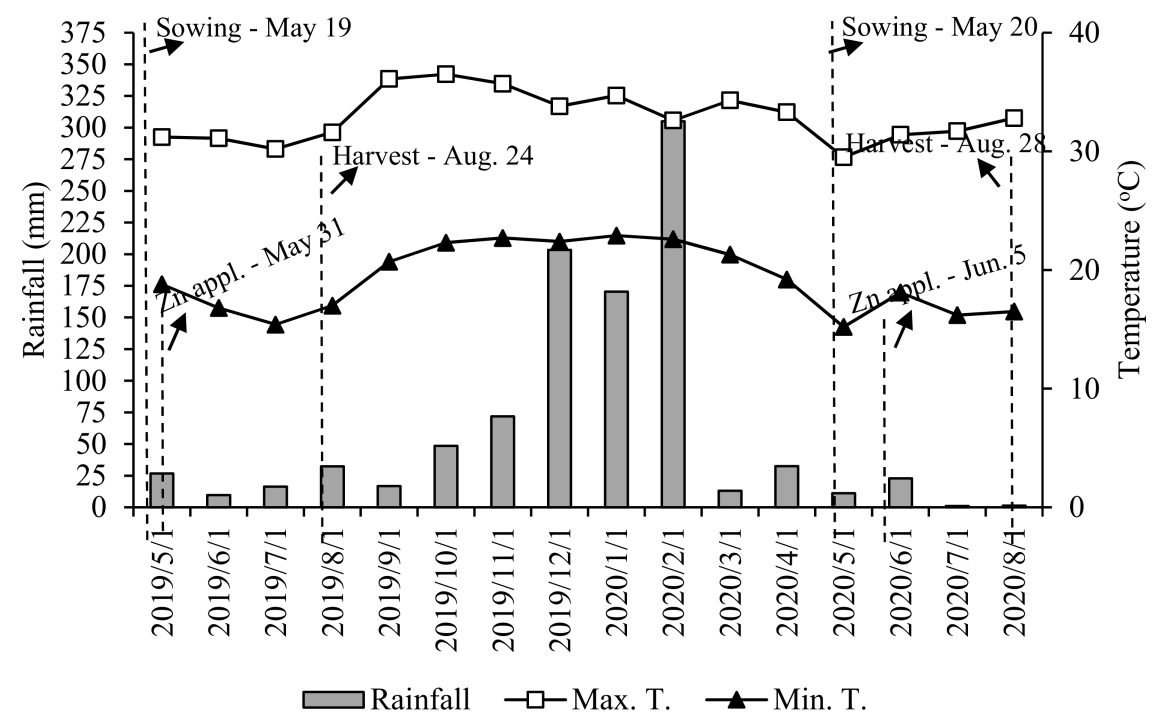

Figure 2. Rainfall maximum, average, and minimum temperatures and air relative humidity were acquired from the weather station of the Education and Research Farm of the Faculty of EngineeringUNESP during the common bean cultivation period from May to August 2019 and May to August 2020 . 


\subsection{Soil Analysis}

A composite soil sample was collected from the experimental site in the soil layer of $0-0.20 \mathrm{~m}$ depth for the pre-experimental soil physio-chemical analysis, following the standard procedures of Raij et al. [38]. Table 1 indicates the physio-chemical attributes of the study area, which is clayey and slightly acidic with a minimal $\mathrm{Zn}$ concentration.

Table 1. Analyzed results of soil sample $(0-0.20 \mathrm{~m})$ from experimental site before experiment implementation. UNESP_-Ilha Solteira, Selvíria, state of Mato Grosso do Sul, Brazil, 2019.

\begin{tabular}{ccc}
\hline Properties & Units & Values \\
\hline Clay & $\mathrm{g} \mathrm{kg}^{-1}$ & 433 \\
Sand & $\mathrm{g} \mathrm{kg}^{-1}$ & 471 \\
Silt & $\mathrm{g} \mathrm{kg}^{-1}$ & 90 \\
pH $\left(\mathrm{CaCl}_{2}\right)$ & - & 5.2 \\
Organic matter & $\mathrm{mg} \mathrm{dm}^{-3}$ & 18 \\
P (resin) & $\mathrm{mg} \mathrm{dm}^{-3}$ & 38 \\
K & $\mathrm{mmol}_{\mathrm{c}} \mathrm{dm}^{-3}$ & 1.7 \\
Ca & $\mathrm{mmol}_{\mathrm{c}} \mathrm{dm}^{-3}$ & 21 \\
Mg & $\mathrm{mmol}_{\mathrm{c}} \mathrm{dm}^{-3}$ & 15 \\
B (hot water) & $\mathrm{mg} \mathrm{dm}^{-3}$ & 0.14 \\
Cu (DTPA) & $\mathrm{mg} \mathrm{dm}^{-3}$ & 3.4 \\
Fe (DTPA) & $\mathrm{mg} \mathrm{dm}^{-3}$ & 25 \\
Zn (DTPA) & $\mathrm{mg} \mathrm{dm}^{-3}$ & 0.9 \\
Mn (DTPA) & $\mathrm{mg} \mathrm{dm}^{-3}$ & 38.1 \\
S-SO & $\mathrm{mg} \mathrm{dm}_{4}^{-3}$ & 4.0 \\
H + Al & $\mathrm{mmol}_{\mathrm{c}} \mathrm{dm}^{-3}$ & 34 \\
CEC (pH 7.0) & $\mathrm{mmol}_{\mathrm{c}} \mathrm{dm}^{-3}$ & 75.7 \\
V & $\%$ & 50 \\
\hline
\end{tabular}

CEC: cation exchange capacity; V: base saturation; DTPA: diethylenetriaminepentaacetic acid.

\subsection{Experimental Design and Treatments}

The experimental design for the common bean crop was randomized, with complete blocks having a $7 \times 2$ factorial scheme with four replications. The experimental factors were comprised of bacterial seeds inoculations (1-No inoculation, 2-Rhizobium tropici, 3-R. tropici + Azospirillum brasilense, 4-R. tropici + Bacillus subtilis, 5-R. tropici + Pseudomonas fluorescens, $6-R$. tropici $+A$. brasilense $+B$. subtilis, and 7-R. tropici + A. brasilense + P. fluorescens), without and with soil applied $\mathrm{Zn}\left(0\right.$ and $\left.8 \mathrm{~kg} \mathrm{Zn} \mathrm{ha}^{-1}\right)$.

The inoculation of common beans with $R$. tropici was carried out using a commercial peat inoculant, strain SEMIA 4080, with $2 \times 10^{9}$ colony forming units (CFU) $\mathrm{g}^{-1}$ at a dose of $200 \mathrm{~g}$ for every $100 \mathrm{~kg}$ of seeds. To facilitate inoculant adhesion with the seeds, a 10\% sugar solution was used to properly and homogeneously mix the seeds. The product is commercially registered with the Ministry of Agriculture and Livestock, Brazil. The inoculation of bacterium A. brasilense strains Ab-V5 and Ab-V6 (strains CNPSo $2083=\mathrm{Ab}$ V5 and CNPSo $2084=\mathrm{Ab}-\mathrm{V} 6$ with a guarantee of $2 \times 10^{8} \mathrm{CFU} \mathrm{mL}{ }^{-1}$ ) was performed at a dose of $300 \mathrm{~mL}$ of inoculant (liquid) per hectare of sown seeds. The inoculation of $B$. subtilis (strain CCTB04 with a guarantee of $1 \times 10^{8} \mathrm{CFU} \mathrm{mL}^{-1}$ ) and P. fluorescens (strain CCTB03 with a guarantee of $2 \times 10^{8} \mathrm{CFU} \mathrm{mL}{ }^{-1}$ ) were applied at a dose of $150 \mathrm{~mL} \mathrm{ha}^{-1}$, according to the recommendation of the inoculant providing company ${ }^{\circledR}$ Total Biotechnology, Curitiba, Brazil. Inoculation was performed an hour before plantation of the crop.

Zinc was applied from a source of zinc sulfate $(21 \% \mathrm{Zn}$ and $11 \%$ of $\mathrm{S})$ to the soil surface by side dressing cover. Zinc doses $\left(0\right.$ and $\left.8 \mathrm{~kg} \mathrm{ha}^{-1}\right)$ were manually applied with an even distribution and without incorporation on the soil surface. The $\mathrm{Zn}$ dose applied to the soil is based on [39,40], who recommended 5 to $30 \mathrm{~kg} \mathrm{ha}^{-1}$ to the soil. The amount of $\mathrm{Zn}$ per treatment per plot was applied at the V1/V2 stage ( $1 / 2$ trifoliate leaves completely unfolded) in both 2019 and 2020 cropping seasons. The experimental area was irrigated 
with a central pivot irrigation system $(14 \mathrm{~mm})$ to evenly incorporate the $\mathrm{Zn}$ fertilizer into the soil.

\subsection{Plant Materials}

The sowing bed was sprayed with systemic (selective) herbicide $\left(2,4-\mathrm{D}-670 \mathrm{~g} \mathrm{ha}^{-1}\right.$ of the active ingredient (AI)) and a broad-spectrum herbicide (glyphosate, $1800 \mathrm{~g} \mathrm{ha}^{-1}$ of AI) 15 days before the experiment implementation for controlling already emerged narrow and broad leaved weeds. The common bean cultivar (IPR-Campos Gerais) with potential quality and production was sown in May, 2019, and repeated in May, 2020, on no-tillage beds using the drill sowing method. The seeds of beans were treated with piraclostrobin $\left(2.5 \% \mathrm{~m} \mathrm{v}^{-1}\right)$, thiophanate methyl $\left(22.5 \% \mathrm{~m} \mathrm{v}^{-1}\right)$, and fipronil $\left(71.3 \% \mathrm{~m} \mathrm{v}^{-1}\right)$, based on the recommended dose of the cultivar. The plots were composed of six lines with a plot size of $2.7 \times 4.5 \mathrm{~m}$, totalizing $12.15 \mathrm{~m}^{2}$. The recommended dose of NPK was applied at

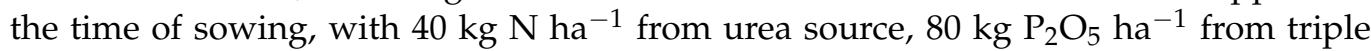
superphosphate source, and $40 \mathrm{~kg} \mathrm{~K}_{2} \mathrm{O} \mathrm{ha}{ }^{-1}$ as potassium chloride. The recommended dose of $90 \mathrm{~kg} \mathrm{~N} \mathrm{ha}^{-1}$ was applied from ammonium sulphate fertilizer after 30 days of emergence. The experimental area was limited with B, according to the interpretation of the Campinas Agronomic Institute (IAC) [38], so the total experimental area was treated with $1 \mathrm{~kg} \mathrm{~B} \mathrm{ha}^{-1}$ as boric acid through a tractor sprayer machine. Irrigation by sprinkling was done with a central-pivot irrigation system, according to the crop need.

\subsection{Evaluations and Analysis}

\subsubsection{Zinc Soil and Plant Nutritional Analysis}

The Zn soil analysis was performed three days after harvest in both the 2019 and 2020 study years. Five samples were collected with an auger $(0.0-0.20 \mathrm{~m})$ from each treatment of each replication and mixed together to obtain a uniform sample of each treatment. The homogeneous sample was collected in separate and already labeled bags. The collected samples were air dried, sieved with a sieving net of $2 \mathrm{~mm}$, and stored at room temperature until the $\mathrm{Zn}$ analysis. The $\mathrm{Zn}$ analyses were performed as described by Raij et al. [38].

The plant material (leaf, straw, and grain) was collected in proper labeled paper bags and dried in an air-tight oven at $60 \pm 5^{\circ} \mathrm{C}$ for $72 \mathrm{~h}$ until it attained a uniform humidity. The material was then ground in a stainless-steel Wiley knife mill by passing it through a 10-mesh sieve and was then placed in labeled plastic containers. Each sample was weighed $(0.25 \mathrm{~g})$, digested with nitroperchloric digestion $\left(\mathrm{HNO}_{3}: \mathrm{HClO}_{4}\right.$ solution), and quantified by atomic absorption spectrophotometry. The analysis was developed following the methodology of Malavolta et al. [41].

\subsubsection{Shoot Dry Matter and Yield}

Plant height at maturity was determined with a ruler from the ground to the upper apex. Shoot dry matter was determined after harvest of four useful central lines. Common bean were harvested and packed in jute bags and then dried in the shade for approximately 1 week. Each plot sample was threshed with an electric thresher to attain the weight of the processed grains for calculating yield ha ${ }^{-1}$ (productivity at $13 \%$ moisture content). After drying, the beans were ground in a Wiley mill for analysis of nutrients.

\subsubsection{Zn Plant Accumulation}

The $\mathrm{Zn}$ accumulation in shoot and grains $\left(\mathrm{g} \mathrm{ha}^{-1}\right)$ was calculated via the following formula:

$$
\begin{aligned}
\mathrm{ZnSA} & =\frac{\text { Zinc concentration in shoot } \times \text { dry matter }}{1000} \\
\mathrm{ZnGA} & =\frac{\text { Zinc concentration in grains } \times \text { grain yield }}{1000}
\end{aligned}
$$

where ZnSA = Shoot Zn accumulation and ZnGA = Grain Zn accumulation. 


\subsubsection{Zinc Partitioning and Intake}

Zinc partitioning index (ZPI) toward grains and intake were calculated following standard methodology of $[42,43]$ :

$$
\begin{gathered}
\mathrm{ZPI}=\frac{\text { Zinc concentration in grains }}{\text { Zinc concentration in shoot }} \times 100 \\
\text { Zn intake }=[\mathrm{Zn}] \times \mathrm{C}
\end{gathered}
$$

where $\mathrm{Zn}$ intake (g person ${ }^{-1}$ day $^{-1}$ ) is the daily $\mathrm{Zn}$ intake of an estimated person ${ }^{-1}$, [Zn] $\left(\mathrm{g} \mathrm{kg}^{-1}\right)$ is the $\mathrm{Zn}$ concentration in biofortified grains from the current study results, and $\mathrm{C}$ $\left(\mathrm{kg}\right.$ person ${ }^{-1}$ day $\left.^{-1}\right)$ is the mean consumption of common bean grains per person in Brazil.

\subsubsection{Zinc Use Efficiency}

The following $\mathrm{Zn}$ use efficiencies were calculated following measurements based on the standards of [44] via the formula:

$$
\begin{gathered}
\text { ZnUE }=\frac{\text { Grain yield } \mathrm{ZnF}-\text { Grain yield } \mathrm{ZnW}}{\mathrm{Applied} \mathrm{Zn} \text { dose }} \\
\mathrm{APE}=\frac{\text { Grain yield } \mathrm{ZnF}-\text { Grain yield } \mathrm{ZnW}}{\mathrm{ZnA} \text { in grain and shoot } \mathrm{ZnF}-\mathrm{ZnA} \text { in grain and shoot } \mathrm{ZnW}} \\
\mathrm{RAZn}(\%)=\frac{\mathrm{ZnA} \text { in grain and shoot } \mathrm{ZnF}-\mathrm{ZnA} \text { in grain and shoot } \mathrm{ZnW}}{\mathrm{Applied} \mathrm{Zn} \text { dose }} \\
\mathrm{UE}=\mathrm{PE} \times \mathrm{RAZn}
\end{gathered}
$$

where ZnUE = Zinc use efficiency, APE = Agro-physiological efficiency, RAZn = Recovery of applied $\mathrm{Zn}, \mathrm{UE}=$ Utilization efficiency, $\mathrm{PE}=$ physiological efficiency, $\mathrm{ZnF}=\mathrm{Zn}$ fertilized treatments, $\mathrm{ZnW}=$ without $\mathrm{Zn}$ fertilized treatments, and $\mathrm{ZnA}=\mathrm{Zn}$ accumulated.

\subsection{Statistical Analysis}

All data were initially tested for normality using Shapiro and Wilk tests, which showed that the data were normally distributed $(\mathrm{W} \geq 0.90)$. Levene's homoscedasticity tests $(p \leq 0.05)$ were performed to access the equality of variances. Afterwards, data were subjected to an analysis of variance ( $\mathrm{F}$ test). The $\mathrm{Zn}$ soil application and diazotrophic bacterial inoculations and their interactions were considered fixed effects in the model. When a main effect or interaction was observed to be significant by the $\mathrm{F}$ test $(p \leq 0.05)$, the Tukey test $(p \leq 0.05)$ was used for comparison of the means of $\mathrm{Zn}$ soil application, whereas the Scott Knott test $(p \leq 0.05)$ was used for comparison of diazotrophic bacterial inoculations using the ExpDes package in R software (R Development Core Team, 2015). The graphics are made in sigma-plot 12.5.

Pearson correlation analysis $(p \leq 0.05)$ was performed using R software ( $R$ Development Core Team). To create a heatmap, the corrplot package was used, using the "color" and "cor.mtest" functions to calculate the coefficients and $p$-value matrices. Asterisks were added to the heatmap cells to identify significant correlations.

\section{Results}

\subsection{Zinc Nutrition in Soil, Plants and Grains}

The plant and grain $\mathrm{Zn}$ concentration of common bean were improved with the application of $\mathrm{Zn}$ to the soil in top dressing and co-inoculations of different diazotrophic bacteria (Table 2). 
Table 2. Zinc concentration in soil, leaf, shoot, and grain of common bean under the influence of diazotrophic bacteria and soil applied zinc doses. Selvíria-MS, Brazil, 2019 and 2020.

\begin{tabular}{|c|c|c|c|c|c|c|c|c|}
\hline Treatments & \multicolumn{2}{|c|}{$\begin{array}{c}\text { Zn-Soil } \\
\text { Concentration }\end{array}$} & \multicolumn{2}{|c|}{$\begin{array}{c}\text { Zn-Leaf } \\
\text { Concentration }\end{array}$} & \multicolumn{2}{|c|}{$\begin{array}{c}\text { Zn-Shoot } \\
\text { Concentration }\end{array}$} & \multicolumn{2}{|c|}{$\begin{array}{l}\text { Zn-Grains } \\
\text { Concentration }\end{array}$} \\
\hline \multicolumn{3}{|c|}{$\mathrm{mg} \mathrm{dm}^{-3}$} & \multicolumn{6}{|c|}{$\mathrm{mg} \mathrm{kg}^{-1}$} \\
\hline & 2019 & 2020 & 2019 & 2020 & 2019 & 2020 & 2019 & 2020 \\
\hline \multicolumn{9}{|c|}{ Zinc $(\mathrm{Zn})$ application $\left(\mathrm{kg} \mathrm{ha}^{-1}\right)$} \\
\hline 0 & $2.8 \mathrm{~b}$ & $4.6 \mathrm{~b}$ & $35.9 \mathrm{~b}$ & $42.7 \mathrm{~b}$ & $30.7 \mathrm{~b}$ & $41.1 \mathrm{~b}$ & $47.4 \mathrm{~b}$ & $54.0 \mathrm{~b}$ \\
\hline 8 & $3.7 \mathrm{a}$ & $6.5 \mathrm{a}$ & $38.2 \mathrm{a}$ & $46.4 \mathrm{a}$ & $38.6 \mathrm{a}$ & $46.6 \mathrm{a}$ & $48.6 \mathrm{a}$ & $56.5 \mathrm{a}$ \\
\hline \multicolumn{9}{|c|}{ Diazotrophic bacterial inoculations (I) } \\
\hline Without & $2.7 \mathrm{c}$ & $4.8 \mathrm{c}$ & $33.3 \mathrm{~b}$ & $40.6 \mathrm{~b}$ & $27.8 \mathrm{c}$ & $41.2 \mathrm{~d}$ & $43.4 \mathrm{e}$ & $52.5 \mathrm{~d}$ \\
\hline R. tropici & $2.7 \mathrm{c}$ & $5.6 \mathrm{~b}$ & $36.7 \mathrm{~b}$ & $42.6 \mathrm{~b}$ & $29.8 \mathrm{c}$ & $43.4 \mathrm{c}$ & $47.0 \mathrm{c}$ & $54.5 \mathrm{c}$ \\
\hline R. tropici + A. brasilense & $3.5 \mathrm{~b}$ & $5.7 \mathrm{~b}$ & $40.4 \mathrm{a}$ & $56.7 \mathrm{a}$ & $33.7 \mathrm{~b}$ & $45.5 \mathrm{~b}$ & $49.3 \mathrm{~b}$ & $57.0 \mathrm{~b}$ \\
\hline R. tropici + B. subtilis & $4.6 \mathrm{a}$ & $7.8 \mathrm{a}$ & $42.8 \mathrm{a}$ & $45.5 \mathrm{~b}$ & $39.6 \mathrm{a}$ & $48.5 \mathrm{a}$ & $54.5 \mathrm{a}$ & $60.7 \mathrm{a}$ \\
\hline R. tropici $+P$. fluorescens & $3.5 \mathrm{~b}$ & $5.5 \mathrm{~b}$ & $36.6 \mathrm{~b}$ & $43.5 \mathrm{~b}$ & $42.0 \mathrm{a}$ & $43.7 c$ & $48.8 \mathrm{~b}$ & $53.7 \mathrm{~d}$ \\
\hline $\begin{array}{c}\text { R. tropici }+ \text { A. brasilense }+ \\
\text { B. subtilis }\end{array}$ & $3.5 \mathrm{~b}$ & $4.8 \mathrm{c}$ & $35.2 \mathrm{c}$ & $43.3 \mathrm{~b}$ & 39.8 a & $42.8 \mathrm{c}$ & $47.1 \mathrm{c}$ & $55.2 \mathrm{c}$ \\
\hline $\begin{array}{c}\text { R. tropici }+ \text { A. brasilense }+ \\
\text { P. fluorescens }\end{array}$ & $2.7 \mathrm{c}$ & $4.2 \mathrm{c}$ & $34.5 \mathrm{~b}$ & $39.8 \mathrm{~b}$ & $30.0 \mathrm{c}$ & $41.6 \mathrm{~d}$ & $45.8 \mathrm{~d}$ & $53.1 \mathrm{~d}$ \\
\hline \multicolumn{9}{|c|}{ F-values } \\
\hline $\mathrm{Zn}$ & $86.2^{* *}$ & $112 * *$ & $6.7 *$ & $9.1 *$ & $85.4^{* *}$ & $239 * *$ & $5.3^{*}$ & $67.3^{* *}$ \\
\hline $\mathrm{I}$ & $25.3^{* *}$ & $23^{* *}$ & $9.2^{* *}$ & $12.4^{* *}$ & $25.9^{* *}$ & $28.4^{* *}$ & $24.1^{* *}$ & $48.1^{* *}$ \\
\hline $\mathrm{Zn} \times \mathrm{I}$ & $7.8^{* *}$ & $20^{* *}$ & $0.9 \mathrm{~ns}$ & $0.4 \mathrm{~ns}$ & $5.8 *$ & $1.2 \mathrm{~ns}$ & $1.8 \mathrm{~ns}$ & $1.6 \mathrm{~ns}$ \\
\hline CV $(\%)$ & 10.7 & 12.3 & 8.6 & 10.2 & 9.2 & 3.0 & 4.35 & 2.09 \\
\hline
\end{tabular}

Means in the column followed by different letters are significantly different $(p$-value $\leq 0.05) ;{ }^{* *}$ and ${ }^{*}$ - significant at $p<0.01$ and $p<0.05$, respectively; ns-non-significant, by F-test.

The soil Zn application and diazotrophic bacterial co-inoculation and their interactions significantly influenced soil $\mathrm{Zn}$ concentration after crop harvest for the study years of 2019 and 2020 (Table 2). The concentration of $\mathrm{Zn}$ in the soil after crop harvest was elevated with soil $\mathrm{Zn}$ application in combination with diazotrophic bacterial inoculations. Soil $\mathrm{Zn}$ application in side dressing had increased soil $\mathrm{Zn}$ concentration by 31.1 and $42.2 \%$ when compared with no Zn application in 2019 and 2020, respectively. Inoculation of seeds with $R$. tropici + B. subtilis prominently increased soil Zn concentration by 67 and $62 \%$ in both years, respectively, in comparison to non-inoculated treatments. The interaction of soil applied $\mathrm{Zn}$ and bacterial inoculation were also significant (Figure 3A,B) in both 2019 and 2020. In addition, co-inoculation of R. tropici + B. subtilis in 2019 resulted in higher soil Zn concentration, irrespective of Zn fertilization, whereas in 2020, higher soil $Z n$ concentration was observed for $R$. tropici $+P$. fluorescens in the treatments without $Z n$ application (Figure 3A,B).

The analysis indicated that $\mathrm{Zn}$ leaf concentrations were different in both of the study years. The leaf $\mathrm{Zn}$ concentration of common bean was significantly influenced by soil $\mathrm{Zn}$ application and diazotrophic bacteria co-inoculations, whereas their interactions were insignificant (Table 2). The leaf $\mathrm{Zn}$ concentration was higher by $8.6 \%$ with soil $\mathrm{Zn}$ application in 2020 and $6.2 \%$ in 2019, in comparison to plots without Zn being applied. The effect of diazotrophic bacteria co-inoculations was also significant and indicated that Zn leaf concentration was increased by 29 and $40 \%$, respectively, with co-inoculation of $R$. tropici $+B$. subtilis in both studied years. The leaf $\mathrm{Zn}$ concentration was $38 \%$ higher in 2020 than in 2019 for the treatments of R. tropici + B. subtilis. In both years, the interaction of soil $\mathrm{Zn}$ application and bacterial co-inoculations was not significant for leaf Zn concentration. 


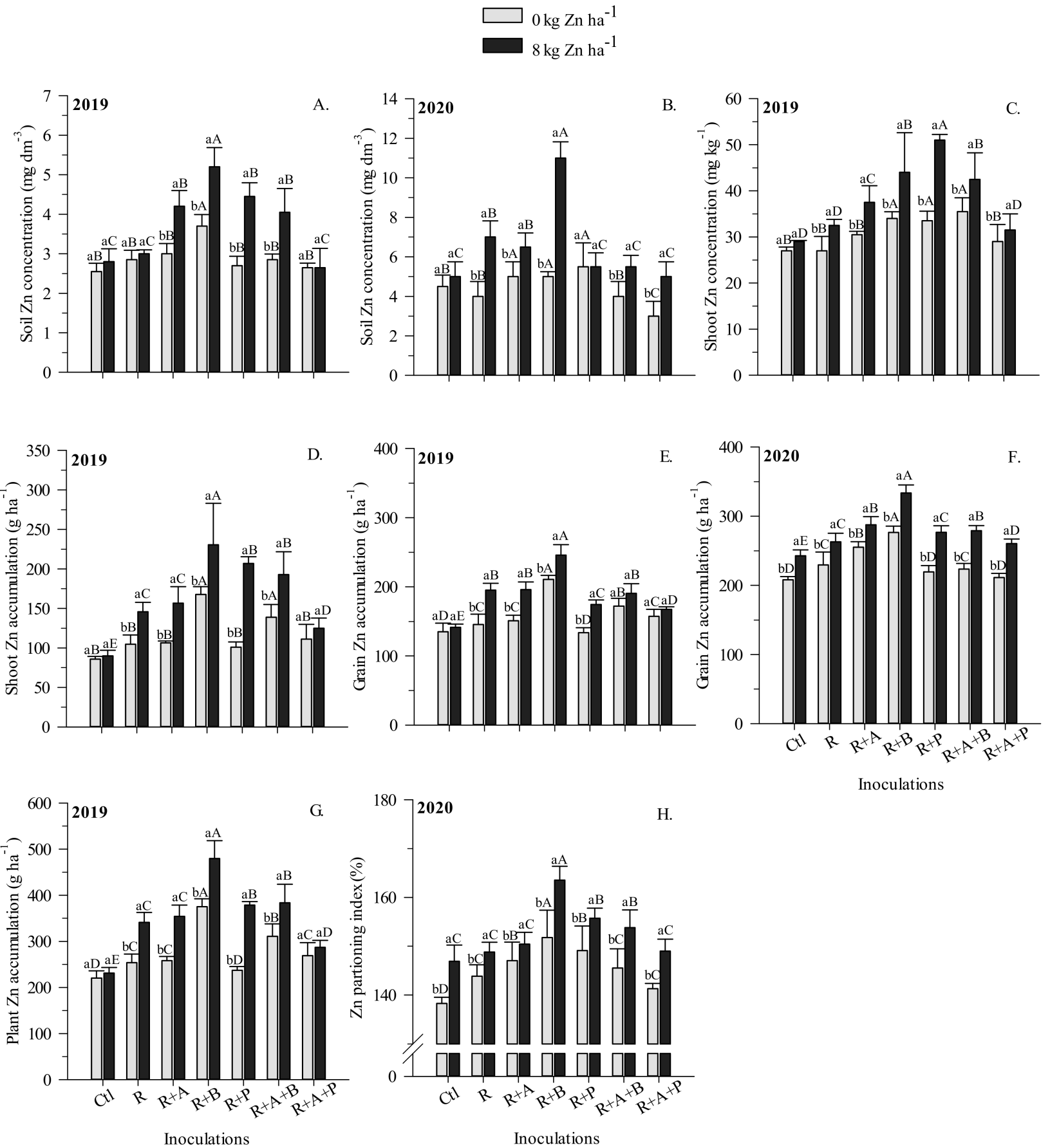

Figure 3. The influence of soil $\mathrm{Zn}$ and co-inoculations of different diazotrophic bacteria on soil $\mathrm{Zn}$ concentration, plant and grain $\mathrm{Zn}$ concentration and accumulation, and $\mathrm{Zn}$ partitioning index in common bean. (A,B) Soil Zn concentration $\left(\mathrm{mg} \mathrm{dm}^{-3}\right)$ in 2019 and 2020, respectively; (C) Shoot Zn concentration (mg) in 2019; (D) Shoot Zn accumulation ( $\mathrm{g} \mathrm{kg}^{-1}$ ) in 2019; (E,F) Grain Zn accumulation $\left(\mathrm{g} \mathrm{kg}^{-1}\right)$ in 2019 and 2020, respectively; (G) Plant Zn (straw + grain) accumulation in 2019; and (H) Zn partitioning index (\%) in 2020. Ctl (No inoculation); R (R. tropici); R + A (R. tropici + A. brasilense); $\mathrm{R}+\mathrm{B}($ R. tropici + B. subtilis $) ; \mathrm{R}+\mathrm{P}($ R. tropici + P. fluorescens $) ; \mathrm{R}+\mathrm{A}+\mathrm{B}($ R. tropici + A. brasilense + B. subtilis $) ;$ and $\mathrm{R}+\mathrm{A}+\mathrm{P}($ R. tropici + A. brasilense $+P$. fluorescens $)$. The uppercase letters are used for inoculation interactions within each level of soil $\mathrm{Zn}$ application, whereas lowercase letters are used for the unfolding of $\mathrm{Zn}$ levels within each inoculation treatment. The identical alphabetic letters do not differ from each other, as analyzed by Tukey (Zn application; $p<0.05)$ and Scott-Knott (inoculations; $p<0.05$ ) tests for 2019 and 2020, respectively. Error bars indicate the standard error of the mean ( $\mathrm{n}=4$ replications). Selvíria, 2020. 
Shoot $\mathrm{Zn}$ concentration was improved with soil applied $\mathrm{Zn}$ and co-inoculation of diazotrophic bacteria in both of the 2019 and 2020 cropping seasons (Table 2). Application of $\mathrm{Zn}$ in side dressing improved shoot $\mathrm{Zn}$ concentration by 26 and $13.3 \%$ in 2019 and 2020 , respectively, when compared to the treatments without $\mathrm{Zn}$ application. The coinoculation of $R$. tropici $+P$. fluorescens improved $\mathrm{Zn}$ shoot concentration by $50.6 \%$ in 2019 , which is statistically similar to values obtained with co-inoculations of $R$. tropici + A. brasilense $+B$. subtilis and $R$. tropici $+B$. subtilis. The $\mathrm{Zn}$ shoot concentration in 2020 was improved by $17.6 \%$ with co-inoculation of $R$. tropici $+B$. subtilis. The interaction of soil applied $\mathrm{Zn}$ and bacterial co-inoculations were significant for $\mathrm{Zn}$ shoot concentration in 2019 (Figure 3C), whereas the interactions of 2020 were not significant (Table 2). However, triple co-inoculation of $R$. tropici $+A$. brasilense $+B$. subtilis was also observed to have higher shoot $\mathrm{Zn}$ concentration in the treatments without soil $\mathrm{Zn}$ application (Figure 3C).

Grain $\mathrm{Zn}$ concentration of common bean was significantly influenced by soil $\mathrm{Zn}$ fertilization and co-inoculations of different diazotrophic bacteria in both 2019 and 2020 (Table 2). The application of $\mathrm{Zn}$ in side dressing was noted to have higher grain $\mathrm{Zn}$ concentration (increased in by 2.7 and $4.7 \%$, respectively) as compared to untreated plots. The co-inoculation of $R$. tropici $+B$. subtilis was observed to have higher $\mathrm{Zn}$ grain concentrations (25.7 and $15.7 \%$ for 2019 and 2020, respectively) in comparison to the control treatments. The interactions for grain $\mathrm{Zn}$ concentrations in both years were not significant (Table 2).

\subsection{Zinc Accumulation in Plant and Grains, and Partitioning Index (ZPI)}

Zinc accumulation in shoot, plant, and grains and the Zn partitioning index of common beans had a positive relation with soil $\mathrm{Zn}$ application and co-inoculation of different diazotrophic bacteria in both cropping seasons (Table 3).

Table 3. Zinc accumulation in shoot, grain, and plant (straw + grain), and Zn partitioning index of common bean, as influenced by diazotrophic bacteria and soil Zn application. Selvíria-MS, Brazil, 2019 and 2020.

\begin{tabular}{|c|c|c|c|c|c|c|c|c|}
\hline \multirow[t]{3}{*}{ Treatments } & \multicolumn{2}{|c|}{$\begin{array}{c}\text { Zn-Shoot } \\
\text { Accumulation }\end{array}$} & \multirow{2}{*}{\multicolumn{2}{|c|}{$\begin{array}{c}\begin{array}{c}\text { Zn Grain } \\
\text { Accumulation }\end{array} \\
\mathrm{g} \mathrm{ha}^{-1}\end{array}$}} & \multicolumn{2}{|c|}{$\begin{array}{c}\text { Zn-Plant } \\
\text { Accumulation }\end{array}$} & \multicolumn{2}{|c|}{ Zn Partitioning Index } \\
\hline & \multirow[b]{2}{*}{2019} & \multirow[b]{2}{*}{2020} & & & & & & \\
\hline & & & 2019 & 2020 & 2019 & 2020 & 2019 & 2020 \\
\hline \multicolumn{9}{|c|}{ Zinc (Zn) application $\left(\mathrm{kg} \mathrm{ha}^{-1}\right)$} \\
\hline 0 & $116 \mathrm{~b}$ & $161 \mathrm{~b}$ & $159 \mathrm{~b}$ & $233 \mathrm{~b}$ & $276 \mathrm{~b}$ & $394 b$ & $122 \mathrm{~b}$ & $145 \mathrm{~b}$ \\
\hline 8 & 166 a & 189 a & $187 \mathrm{a}$ & 277 a & $340 \mathrm{a}$ & 466 a & $133 \mathrm{a}$ & $152 \mathrm{a}$ \\
\hline \multicolumn{9}{|c|}{ Diazotrophic bacterial inoculations (I) } \\
\hline Without & $89 \mathrm{~d}$ & $162 \mathrm{c}$ & $140 \mathrm{e}$ & $223 \mathrm{e}$ & $244 \mathrm{f}$ & $386 \mathrm{~d}$ & $126 \mathrm{~b}$ & $142 \mathrm{e}$ \\
\hline R. tropici & $124 \mathrm{c}$ & $176 \mathrm{~b}$ & $173 \mathrm{~b}$ & $250 \mathrm{c}$ & $295 \mathrm{~d}$ & $426 \mathrm{c}$ & $126 \mathrm{~b}$ & $146 \mathrm{~d}$ \\
\hline R. tropici + A. brasilense & $133 c$ & $191 \mathrm{a}$ & $170 \mathrm{~b}$ & $271 \mathrm{~b}$ & $300 \mathrm{~d}$ & $461 \mathrm{~b}$ & $123 \mathrm{~b}$ & $149 \mathrm{c}$ \\
\hline R. tropici + B. subtilis & $202 \mathrm{a}$ & $188 \mathrm{a}$ & $228 \mathrm{a}$ & 307 a & $386 \mathrm{a}$ & $496 \mathrm{a}$ & $137 \mathrm{a}$ & $158 \mathrm{a}$ \\
\hline R. tropici + P. fluorescens & $153 \mathrm{~b}$ & $174 \mathrm{~b}$ & $155 \mathrm{~d}$ & $246 c$ & $318 \mathrm{c}$ & $420 \mathrm{c}$ & $125 \mathrm{~b}$ & $152 \mathrm{~b}$ \\
\hline $\begin{array}{c}\text { R. tropici }+ \text { A. brasilense }+ \\
\text { B. subtilis }\end{array}$ & $170 \mathrm{~b}$ & $173 \mathrm{~b}$ & $180 \mathrm{~b}$ & $252 c$ & $338 \mathrm{~b}$ & $425 c$ & $129 \mathrm{~b}$ & $149 \mathrm{c}$ \\
\hline $\begin{array}{c}\text { R. tropici }+ \text { A. brasilense }+ \\
\text { P. fluorescens }\end{array}$ & $119 \mathrm{c}$ & $163 c$ & $162 \mathrm{c}$ & $234 \mathrm{~d}$ & $277 \mathrm{e}$ & $397 d$ & $129 \mathrm{~b}$ & $144 \mathrm{~d}$ \\
\hline \multicolumn{9}{|c|}{ F-values } \\
\hline $\mathrm{Zn}$ & $122 * *$ & $196^{* *}$ & $97.1 * *$ & $341 * *$ & $208^{* *}$ & $507 * *$ & $54.3^{* *}$ & $138^{* *}$ \\
\hline $\mathrm{I}$ & $38^{* *}$ & $17^{* *}$ & $55.6^{* *}$ & $75.9 * *$ & $60.5^{* *}$ & $79 * *$ & $5.0 *$ & $39 * *$ \\
\hline $\mathrm{Zn} \times \mathrm{I}$ & $7.3^{* *}$ & $1.5 \mathrm{~ns}$ & $6.5^{*}$ & $3.7 *$ & $13.6^{* *}$ & $1.56 \mathrm{~ns}$ & $1.42 \mathrm{~ns}$ & $2.7 *$ \\
\hline CV (\%) & 12.01 & 4.24 & 6.16 & 3.50 & 5.35 & 2.78 & 4.38 & 1.57 \\
\hline
\end{tabular}

Means in the column followed by different letters are significantly different ( $p$-value $\leq 0.05)$; ${ }^{* *}$ and ${ }^{*}$ - significant at $p<0.01$ and $p<0.05$, respectively; and ns-non-significant, by F-test. 
The treatment with soil $\mathrm{Zn}$ application in side dressing significantly improved shoot Zn accumulation in 2019 and 2020 by 43.1 and $17.4 \%$, respectively, as compared to plots without $\mathrm{Zn}$ being applied. The co-inoculation of $R$. tropici + B. subtilis increased shoot $\mathrm{Zn}$ accumulation by $127 \%$ in 2019 whereas, in 2020, shoot $\mathrm{Zn}$ accumulation was improved by $18 \%$ with co-inoculation of $R$. tropici + A. brasilense, which is statistically similar to co-inoculation of $R$. tropici $+B$. subtilis. The interaction of $\mathrm{Zn}$ and the co-inoculation of bacteria in 2019 was significant (Figure 3D), although it was not significant in 2020 (Table 3). The co-inoculation of $R$. tropici $+B$. subtilis also lead to greater shoot $Z n$ accumulation in the treatments without soil $\mathrm{Zn}$ application (Figure 3D).

Grain Zn accumulation was improved in 2019 and 2020 by 17.6 and $18.9 \%$, respectively, with soil Zn application compared to without soil Zn application. The co-inoculation of $R$. tropici + B. subtilis increased grain Zn accumulation by $62.8 \%$ in 2019 and $37.7 \%$ in 2020, respectively, compared to un-inoculated treatments. The interactions of soil applied $\mathrm{Zn}$ and co-inoculation of bacteria were also significant for both the years (Figure 3E,F). The co-inoculation of R. tropici + B. subtilis with and without soil Zn application was noted for higher grain $\mathrm{Zn}$ accumulation, whereas co-inoculation of $R$. tropici $+P$. fluorescens in the absence of $\mathrm{Zn}$ application resulted in lower grain Zn concentrations in both 2019 and 2020 (Figure 3E,F).

Plant (straw + grain) $\mathrm{Zn}$ accumulation was influenced by soil $\mathrm{Zn}$ application and co-inoculation of different diazotrophic bacteria in both of the 2019 and 2020 study years (Table 3). Higher plant Zn accumulations (23.2 and 18.3\%) was noted in the plots treated with $8 \mathrm{~kg} \mathrm{Zn} \mathrm{ha}{ }^{-1}$ as compared to the treatments without $\mathrm{Zn}$ application in 2019 and 2020, respectively. The co-inoculation of $R$. tropici $+B$. subtilis also increased plant $\mathrm{Zn}$ accumulation in 2019 and 2020 (58.2 and 28.5\%, respectively) in comparison to there being no inoculation treatments. The interactions of soil $\mathrm{Zn}$ application and bacterial co-inoculation were found to be significant for plant Zn accumulation in 2019 (Figure 3G), whereas it was not significant in 2020 (Table 3).

The Zinc partitioning index (ZPI) of the grain was significantly increased with soil Zn application and co-inoculation by different diazotrophic bacteria in 2019 and 2020 (Table 3). The interaction of soil $\mathrm{Zn}$ application and co-inoculation of bacteria was not significant in 2019, although, in 2020, it was significant for the ZPI (Figure 3H). The side dressing of Zn at a rate of $8 \mathrm{~kg} \mathrm{Zn} \mathrm{ha}{ }^{-1}$ significantly increased ZPI by 9 and 5\% in 2019 and 2020, respectively, compared to there being no Zn applied treatments (Table 3). The co-inoculation of $R$. tropici + B. subtilis predominantly boosted ZPI by 8.7 and 17.5\% in 2019 and 2020, respectively, when compared to non-inoculated plots. In addition, co-inoculation of $R$. tropici $+B$. subtilis was also observed to have higher ZPI, even in the absence of $\mathrm{Zn}$ application, whereas the lower ZPI was observed in the control treatments (Figure $3 \mathrm{H}$ ).

\subsection{Plant Height, Dry Matter, Grain Yield and Zn Intake}

Plant height of common bean was one of the determining attributes that was significantly influenced by soil Zn application and co-inoculations of different bacteria in 2019, whereas in 2020, plant height was not significantly influenced (Table 4). The plots treated in 2019 and 2020 with Zn fertilizer were seen to have taller plants (7.36 and 5.43\%, respectively) compared to those not fertilized with Zn. In 2019, the co-inoculation with R. tropici+ B. subtilis led to taller plants $(13 \%)$, which was significantly similar to co-inoculation with R. tropici + A. brasilense and $R$. tropici + A. brasilense + B. subtilis (12.6\%). The plant height in 2020 was statistically not different; however, taller plants were observed in the control and the triple co-inoculation of $R$. tropici + A. brasilense + P. fluorescens. The interaction for plant height in 2019 was significant (Figure 4A), and that of 2020 was insignificant (Table 4). In addition, treatments in the absence of $\mathrm{Zn}$ fertilizer were observed, with taller plants under co-inoculation of $R$. tropici $+A$. brasilense and shorter plants with co-inoculation of R. tropici + P. fluorescens (Figure $4 \mathrm{~A}$ ). 
Table 4. Plant height, shoot dry matter, grain yield, and $\mathrm{Zn}$ intake in common bean under the influence of diazotrophic bacteria and soil applied zinc doses. Selvíria-MS, Brazil, 2019 and 2020.

\begin{tabular}{|c|c|c|c|c|c|c|c|c|}
\hline \multirow[t]{3}{*}{ Treatments } & \multirow{2}{*}{\multicolumn{2}{|c|}{$\begin{array}{c}\text { Plant Height } \\
\mathrm{cm}\end{array}$}} & \multicolumn{2}{|c|}{ Shoot Dry Matter } & \multicolumn{2}{|c|}{ Grain Yield } & \multicolumn{2}{|c|}{ Zn Intake } \\
\hline & & & & & & & g Persc & Day $^{-1}$ \\
\hline & 2019 & 2020 & 2019 & 2020 & 2019 & 2020 & 2019 & 2020 \\
\hline \multicolumn{9}{|c|}{ Zinc $(\mathrm{Zn})$ application $\left(\mathrm{kg} \mathrm{ha}^{-1}\right)$} \\
\hline 0 & $95 \mathrm{~b}$ & $92 \mathrm{a}$ & $3934 \mathrm{~b}$ & $3930 \mathrm{~b}$ & $3758 \mathrm{~b}$ & $4303 \mathrm{~b}$ & $6.73 \mathrm{~b}$ & $7.68 \mathrm{~b}$ \\
\hline 8 & $102 \mathrm{a}$ & $97 \mathrm{a}$ & 4040 a & $4075 \mathrm{a}$ & 4269 a & 4888 a & $6.92 \mathrm{a}$ & $8.04 \mathrm{a}$ \\
\hline \multicolumn{9}{|c|}{ Diazotrophic bacterial inoculations (I) } \\
\hline Without (Control) & $92.1 \mathrm{~b}$ & $99.8 \mathrm{a}$ & $3843 \mathrm{~d}$ & $3818 \mathrm{~d}$ & $3268 \mathrm{e}$ & $4252 \mathrm{e}$ & $6.16 \mathrm{e}$ & $7.46 \mathrm{~d}$ \\
\hline R. tropici & $98.6 \mathrm{~b}$ & $94.1 \mathrm{a}$ & 3952 c & 3989 c & $4121 \mathrm{~b}$ & 4590 c & $6.68 \mathrm{c}$ & $7.75 \mathrm{c}$ \\
\hline R. tropici + A. brasilense & $103.7 \mathrm{a}$ & $95.4 \mathrm{a}$ & $4060 \mathrm{~b}$ & $4063 \mathrm{~b}$ & $3899 \mathrm{c}$ & $4748 \mathrm{~b}$ & $7.01 \mathrm{~b}$ & $8.11 \mathrm{~b}$ \\
\hline R. tropici + B. subtilis & $104.1 \mathrm{a}$ & $93.0 \mathrm{a}$ & 4207 a & $4164 \mathrm{a}$ & 5069 a & 5052 a & $7.75 \mathrm{a}$ & $8.64 \mathrm{a}$ \\
\hline R. tropici + P. fluorescens & $92.2 \mathrm{~b}$ & $90.1 \mathrm{a}$ & $3978 c$ & $4018 \mathrm{~b}$ & $3542 \mathrm{~d}$ & 4564 c & $6.95 \mathrm{~b}$ & $7.64 \mathrm{~d}$ \\
\hline $\begin{array}{c}\text { R. tropici }+ \text { A. brasilense }+ \\
\text { B. subtilis }\end{array}$ & 103.7 a & $94.1 \mathrm{a}$ & 3962 c & $4012 \mathrm{~b}$ & $4234 \mathrm{~b}$ & 4558 c & $6.70 \mathrm{c}$ & $7.85 \mathrm{c}$ \\
\hline $\begin{array}{c}\text { R. tropici }+ \text { A. brasilense }+ \\
\text { P. fluorescens }\end{array}$ & $96.0 \mathrm{~b}$ & $98.1 \mathrm{a}$ & 3905 d & 3955 c & 3962 c & $4405 \mathrm{~d}$ & $6.52 \mathrm{~d}$ & $7.55 \mathrm{~d}$ \\
\hline \multicolumn{9}{|c|}{ F-values } \\
\hline $\mathrm{Zn}$ & $24.1^{* *}$ & $3.4 \mathrm{~ns}$ & $23.6^{* *}$ & $74.9^{* *}$ & $161^{* *}$ & $306^{* *}$ & $5.3 *$ & $67.2^{* *}$ \\
\hline I & $7.2^{* *}$ & $0.85 \mathrm{~ns}$ & $16.4^{* *}$ & $22.7^{* *}$ & $115^{* *}$ & $33.1^{* *}$ & 22.1 * & $48.2^{* *}$ \\
\hline $\mathrm{Zn} \times \mathrm{I}$ & $4.8^{*}$ & $0.84 \mathrm{~ns}$ & $0.13 \mathrm{~ns}$ & $2.68 *$ & $10.2^{* *}$ & $5.1^{* *}$ & $1.8 \mathrm{~ns}$ & $1.7 \mathrm{~ns}$ \\
\hline CV (\%) & 5.71 & 10.44 & 2.06 & 1.56 & 3.76 & 2.72 & 4.35 & 2.09 \\
\hline
\end{tabular}

Means in the column followed by different letters are significantly different $(p$-value $\leq 0.05) ;{ }^{* *}$ and ${ }^{*}$-significant at $p<0.01$ and $p<0.05$, respectively; and ns-non-significant, by F-test.

Soil Zn application at sowing and co-inoculation of different diazotrophic bacteria significantly influenced the shoot dry matter of common bean in both of the 2019 and 2020 study years (Table 4). Shoot dry matter was increased by 2.7 and $3.6 \%$ in the presence of Zn fertilization in 2019 and 2020, respectively, compared to the treatments without Zn application. The co-inoculation of $R$. tropici $+B$. subtilis increased shoot dry matter by 9.5 and $9.1 \%$ in 2019 and 2020, respectively, compared to the control. The interaction for shoot dry matter in the first season was not significant (Table 4), whereas, in the second crop season, interaction was significant (Figure 4B).

Grain yield of common bean was significantly influenced by soil $\mathrm{Zn}$ application in combination with different diazotrophic bacteria in 2019 and 2020 (Table 4). The interactions of $\mathrm{Zn}$ and co-inoculations of bacteria were significant for both years (Figure 4C,D). Grain yield of common bean was increased by 13.6 and $13.5 \%$ in 2019 and 2020, respectively, under the treatments with soil applied $\mathrm{Zn}$ when compared to the treatments without $\mathrm{Zn}$ application. The co-inoculation of $R$. tropici + B. subtilis increased the grain yield of common bean by 54.3 and $18.9 \%$ in 2019 and 2020, respectively, compared to the control plots. In addition, co-inoculation of R. tropici $+B$. subtilis was observed for higher grain yield, irrespective of $\mathrm{Zn}$ application in both study years (Figure 4C,D). However, lower grain yield was observed with co-inoculation of $R$. tropici + P. fluorescens in 2019 (Figure 4C) and without inoculation in 2020 (Figure 4D).

The estimation of daily $\mathrm{Zn}$ intake in Brazil was increased with soil $\mathrm{Zn}$ application and co-inoculations of diazotrophic bacteria in 2019 and 2020 (Table 4). The daily consumption of beans in Brazil ( 142.2 g person $^{-1}$ day $\left.^{-1}\right)$ [45] and the results of present grain $\mathrm{Zn}$ concentration and soil $\mathrm{Zn}$ application, along with different diazotrophic co-inoculations, are being calculated to attain $\mathrm{Zn}$ intake $\left(\mathrm{g} \mathrm{person}^{-1}\right.$ day $\left.^{-1}\right)$. The treatments with soil applied Zn were observed to have higher estimated Zn intake in 2019 and 2020 (2.83 and $4.69 \%$, respectively). The co-inoculation of $R$. tropici + B. subtilis increased estimated $\mathrm{Zn}$ intake by $25.8 \%$ in 2019 and $15.8 \%$ in 2020 , compared to the control. The interaction of soil 
Zn application and diazotrophic bacteria was not significant for $\mathrm{Zn}$ intake in both of the study years.

$0 \mathrm{~kg} \mathrm{Zn} \mathrm{ha}{ }^{-1}$

$8 \mathrm{~kg} \mathrm{Zn} \mathrm{ha}{ }^{-1}$
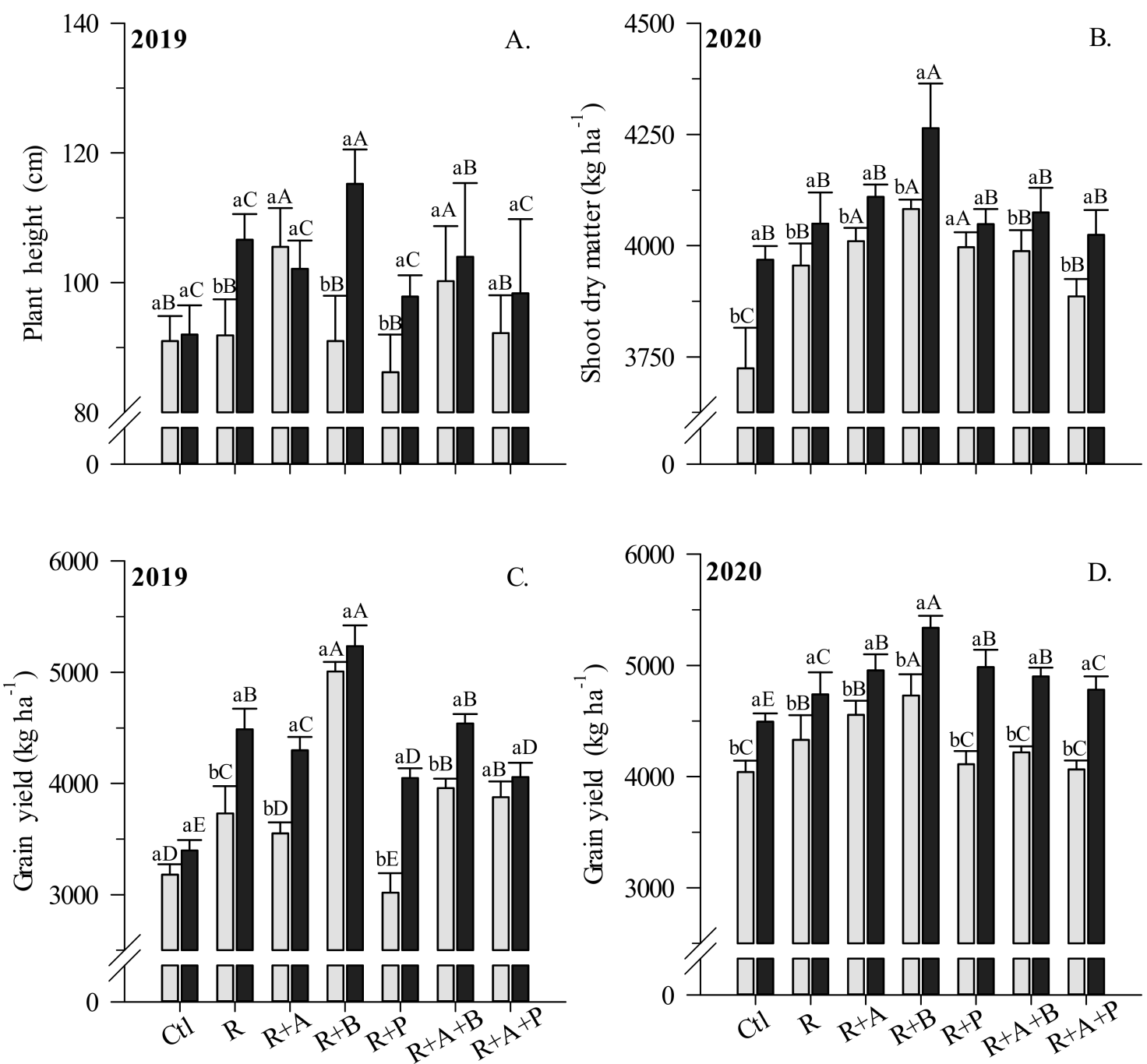

Inoculations

Inoculations

Figure 4. The influence of soil $\mathrm{Zn}$ and co-inoculations on common bean growth attributes and grain yield: (A) Plant height (cm) in 2019; (B) Shoot dry matter $\left(\mathrm{kg} \mathrm{ha}^{-1}\right)$ in 2020; (C,D) Grain yield (kg ha $\left.{ }^{-1}\right)$ in 2019 and 2020, respectively. Ctl (No inoculation); R (R. tropici); R + A (R. tropici + A. brasilense); R + B (R. tropici + B. subtilis); R + P (R. tropici + P. fluorescens); $\mathrm{R}+\mathrm{A}+\mathrm{B}($ R. tropici + A. brasilense + B. subtilis $) ;$ and $\mathrm{R}+\mathrm{A}+\mathrm{P}(\mathrm{R}$. tropici + A. brasilense + P. fluorescens $)$. The uppercase letters are used for inoculation interactions within each level of soil $\mathrm{Zn}$ application, whereas lowercase letters are used for the unfolding of $\mathrm{Zn}$ levels within each inoculation treatment. The identical alphabetic letters do not differ from each other, as analyzed by Tukey (Zn application; $p<0.05$ ) and Scott-Knott (inoculations; $p<0.05$ ) tests for 2019 and 2020, respectively. Error bars indicate the standard error of the mean $(n=4$ replications). Selvíria, 2019 and 2020.

\subsection{Zinc Efficiencies}

Zinc use efficiency (ZnUE) was increased in the treatments of different diazotrophic bacteria in combination with soil $\mathrm{Zn}$ application (Table 5). The effect of bacterial coinoculation was significant for ZnUE in both years. The co-inoculation of $R$. tropici + 
B. subtilis improved ZnUE in 2019 and 2020 (941.6 and 172\%, respectively), compared to control treatments.

Table 5. Zinc efficiencies of common beans under the influence of diazotrophic bacteria and soil applied zinc doses. Selvíria-MS, Brazil, 2019 and 2020.

\begin{tabular}{|c|c|c|c|c|c|c|c|c|}
\hline \multirow[t]{3}{*}{ Treatments } & \multicolumn{2}{|c|}{ ZnUE } & \multicolumn{2}{|c|}{ APE } & \multicolumn{2}{|c|}{ UE } & \multicolumn{2}{|c|}{ AZnR } \\
\hline & \multicolumn{6}{|c|}{$\mathrm{kg} \mathrm{kg}^{-1}$} & \multicolumn{2}{|c|}{$\%$} \\
\hline & 2019 & 2020 & 2019 & 2020 & 2019 & 2020 & 2019 & 2020 \\
\hline \multicolumn{9}{|c|}{ Diazotrophic bacterial inoculations (I) } \\
\hline Without (Control) & $24 \mathrm{~d}$ & $64 \mathrm{~d}$ & $6.95 \mathrm{a}$ & $5.15 \mathrm{c}$ & $41 \mathrm{~d}$ & $133 \mathrm{c}$ & $3 \mathrm{e}$ & $12 \mathrm{~d}$ \\
\hline R. tropici & $168 \mathrm{~b}$ & $104 \mathrm{c}$ & $9.88 \mathrm{a}$ & $6.36 \mathrm{~b}$ & $209 \mathrm{~b}$ & $183 \mathrm{~b}$ & $17 \mathrm{c}$ & $16 \mathrm{c}$ \\
\hline R. tropici + A. brasilense & $140 \mathrm{~b}$ & $123 \mathrm{~b}$ & $7.68 \mathrm{a}$ & $5.90 \mathrm{~b}$ & $228 \mathrm{~b}$ & $208 \mathrm{~b}$ & $18 \mathrm{c}$ & $21 \mathrm{~b}$ \\
\hline R. tropici + B. subtilis & $250 \mathrm{a}$ & $174 \mathrm{a}$ & $7.17 \mathrm{a}$ & $6.56 \mathrm{~b}$ & $447 \mathrm{a}$ & $273 \mathrm{a}$ & $35 \mathrm{a}$ & $26 \mathrm{a}$ \\
\hline R. tropici + P. fluorescens & $106 \mathrm{c}$ & $132 \mathrm{~b}$ & $4.96 \mathrm{a}$ & $7.66 \mathrm{a}$ & $212 b$ & $204 \mathrm{~b}$ & $21 \mathrm{~b}$ & $17 \mathrm{c}$ \\
\hline $\begin{array}{c}\text { R. tropici }+ \text { A. brasilense }+ \\
\text { B. subtilis }\end{array}$ & $167 \mathrm{~b}$ & $121 \mathrm{~b}$ & $7.68 \mathrm{a}$ & $7.02 \mathrm{a}$ & $238 \mathrm{~b}$ & $198 \mathrm{~b}$ & $22 \mathrm{~b}$ & $17 \mathrm{c}$ \\
\hline $\begin{array}{c}\text { R. tropici }+ \text { A. brasilense }+ \\
\text { P. fluorescens }\end{array}$ & $106 \mathrm{c}$ & $104 \mathrm{c}$ & $10.20 \mathrm{a}$ & $7.48 \mathrm{a}$ & $148 \mathrm{c}$ & $175 b$ & $10 \mathrm{~d}$ & $14 \mathrm{~d}$ \\
\hline \multicolumn{9}{|c|}{ F-values } \\
\hline $\mathrm{I}$ & $51 *$ & $16^{*}$ & 2.96 & $9.10 *$ & $44.2 *$ & 13.4 * & $62.2 *$ & 32.4 * \\
\hline $\mathrm{CV}(\%)$ & 14.2 & 13.9 & 26.7 & 8.9 & 16.8 & 11.8 & 13.6 & 9.2 \\
\hline
\end{tabular}

ZnUE = Zinc use efficiency, APE = Agro-physiological efficiency, UE = Utilization efficiency, and AZnR = Applied zinc recovery. Means in the column followed by different letters are significantly different ( $p$-value $\leq 0.05)$; ${ }^{*}$ - significant at $p<0.01$ and $p<0.05$, respectively; and ns-nonsignificant, by F-test.

The co-inoculations of different bacteria along with $\mathrm{Zn}$ application had not significantly affected agro-physiological efficiency (APE) in 2019, whereas the effect was significant in 2020 (Table 5). The highest APE was observed with the triple co-inoculation of $R$. tropici $+A$. brasilense $+P$. fluorescens, which was $46.7 \%$ higher than the control, whereas the lowest APE was observed with R. tropici + P. fluorescens, which was $0.71 \%$ less than the control in 2019. The APE was improved by $48.7 \%$ with triple co-inoculation of $R$. tropici + A. brasilense $+P$. fluorescens, which is statistically similar to co-inoculation of $R$. tropici $+P$. fluorescens (45.2\%) and R. tropici + A. brasilense + B. Subtilis (36.3\%) in 2020, compared to the control plots.

The utilization efficiency (UE) was significantly improved with co-inoculations of different diazotrophic bacteria along with soil Zn application in 2019 and 2020 (Table 5). The co-inoculation of $A$. brasilense $+B$. subtilis prominently increased utilization efficiency in 2019 and 2020 by 990.2 and $105.2 \%$, respectively, compared to the control.

The co-inoculations of different diazotrophic bacteria along with soil applied $\mathrm{Zn}$ improved applied Zn recovery (AZnR) in 2019 and 2020 (Table 5). The co-inoculation of R. tropici + A. brasilense in 2019 and 2020 significantly improved AZnR by 167 and 117\%, respectively, along with soil application of $\mathrm{Zn}$, compared to the control.

\subsection{Pearson's Linear Correlation among Zn Content in Tissues and Soil, Zn Efficiencies and Common Bean Grain Yield}

Pearson's linear correlation was positive between Zn content in soil; Zn concentration in leaf tissue, shoot and grain; Zn accumulated in shoot, grain, and aerial part with shoot biomass; and grain yield (Figure 5). Similarly, Pearson's correlation was positive between Zn use efficiency, agro-physiological efficiency, applied Zn recovery, and utilization efficiency with shoot biomass and common bean grain yield (Figure 5). 


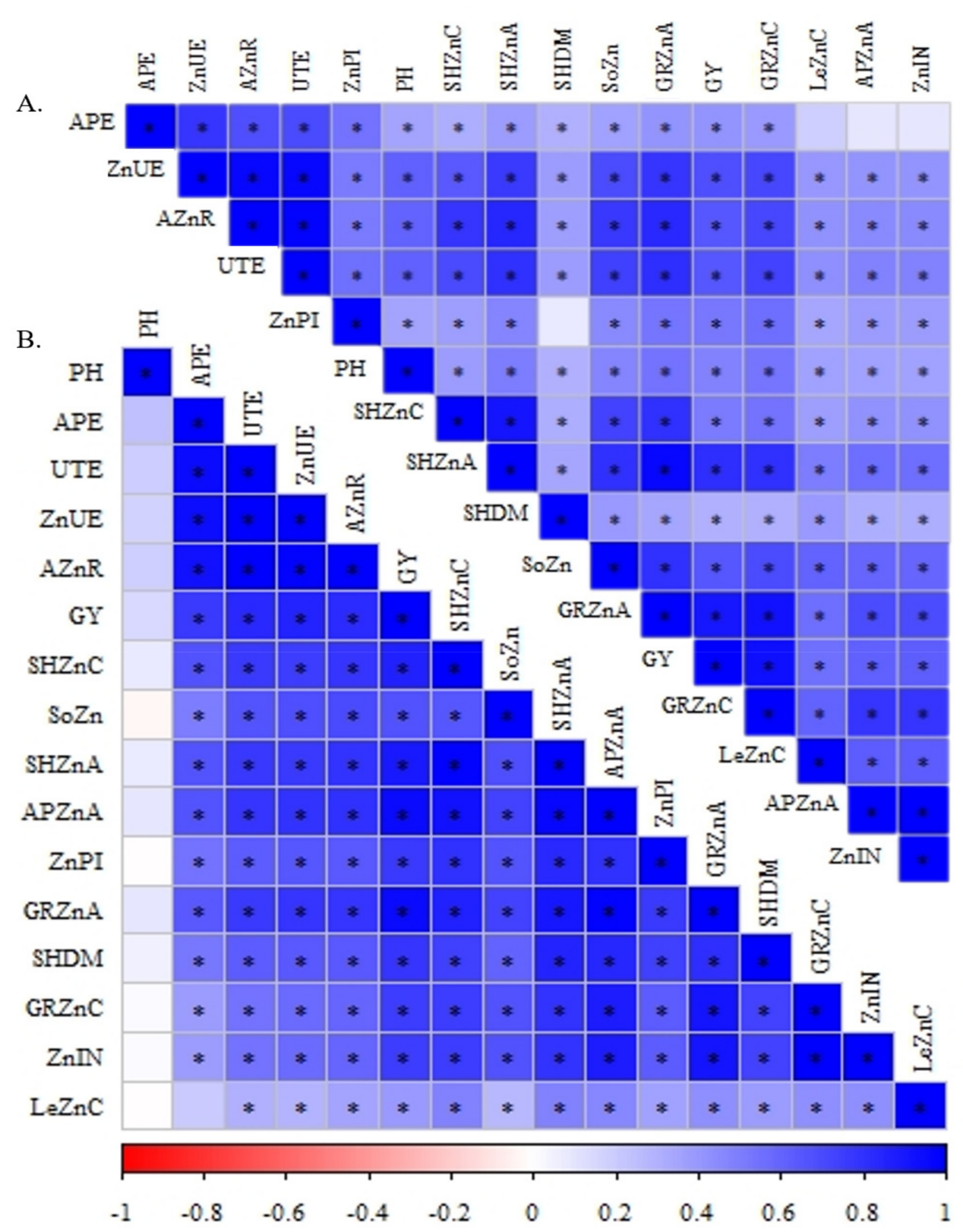

\section{Correlation coefficient}

Figure 5. Heatmap showing Pearson's correlation among the analyzed parameters from soil and common bean plants in response to different soil $\mathrm{Zn}$ applications and diazotrophic bacteria inoculations in the 2019 (A) and 2020 (B) crop seasons. * indicates a significant relationship $(p \leq 0.05)$. Abbreviations: SoZn $=\mathrm{Zn}$ content in soil, LeZnC $=\mathrm{Zn}$ concentration in leaf tissue, SHZnC $=\mathrm{Zn}$ concentration in shoot, $\mathrm{SHZnA}=\mathrm{Zn}$ accumulated in shoot, $\mathrm{APZnA}=\mathrm{Zn}$ accumulated in aerial part (shoot + grain), GRZnC $=\mathrm{Zn}$ concentration in grain, GRZnA $=\mathrm{Zn}$ accumulated in grain, SHDM = shoot dry matter, $\mathrm{GY}=$ grain yield, $\mathrm{PH}=$ plant height, $\mathrm{ZnPI}=\mathrm{Zn}$ partioning index, $\mathrm{ZnIN}=\mathrm{Zn}$ intake, $\mathrm{ZnUE}=\mathrm{Zn}$ use efficiency, APE = Agro-physiological efficiency, AZnR = Applied Zn recovery, and UTE $=$ Utilization efficiency.

\section{Discussion}

Zinc soil application is one the most adaptable strategies to boost $\mathrm{Zn}$ assimilation in plant tissues and grains [26] in Zn deficient soil ranging from 0.0 to $0.3 \mathrm{mg} \mathrm{dm}^{3}$ [46]. In addition, $\mathrm{Zn}$ agronomic application improves different physiological functions and results in better growth, Zn use efficiency, and high productivity $[20,22,26]$. The positive 
Pearson's correlation between $\mathrm{Zn}$ uptake (Zn concentration in soil and tissues and $\mathrm{Zn}$ accumulated in aerial part) and $\mathrm{Zn}$ efficiencies with common bean shoot dry matter and grain yield support this hypothesis (Figure 5).

The inoculation of diazotrophic bacteria can improve Zn solubilization and availability to plants through the production of several phytohormones and enzymes and the biological fixation of nitrogen [23,29]. These bacteria facilitate $\mathrm{Zn}$ assimilation and accumulation through carboxylation and solubilization, unlike sole $\mathrm{Zn}$ applications that generate $\mathrm{Zn}$ toxicity [47]. Zinc is available in different ways over time, which needs further and extensive study to understand the co-inoculation and $\mathrm{Zn}$ dose effect, which will lead to better nutrition, plant physiology, and yield. The soil Zn application with diazotrophic bacteria sustainably increased plant adaptation in tropical regions, leading to the better $\mathrm{Zn}$ nutrition, accumulation, and yield of common bean.

This field study indicated that soil $\mathrm{Zn}$ application and co-inoculations of diazotrophic bacteria improved $\mathrm{Zn}$ soil concentration after common bean harvest (Figure 3A,B) in 2019 and 2020. This improvement might be due to certain metabolic mechanisms that bacteria could adopt to dissolve unavailable soil $\mathrm{Zn}$ through synthesis of reactive products from non-reactive materials [48]. The increase in soil Zn concentration may be due to the positive relationships of different bacteria, including Bacillus and Pseudomonas sp., which potentially improve soil $\mathrm{Zn}$ concentration through carboxylation and different organic acids production $[34,49]$.

The concentration of $\mathrm{Zn}$ in shoots and grains were improved with soil applied $\mathrm{Zn}$ and co-inoculation of different bacteria (Figure 3C; Table 2). The reason for this might be the structural role of bacteria in different metabolic, enzymatic, and biochemical processes [50], which should proactively increase $\mathrm{Zn}$ and other nutrients availability to plants [44]. Plantsmicrobe interaction in root rhizosphere increased $\mathrm{Zn}$ solubilization and availability in the plant tissues of legume crops [51]. Previous studies have shown that the sequencing of bacterial inoculants (especially Bacillus sp.) had the potential to better solubilize $\mathrm{Zn}$ insoluble complexes, including phosphate, oxides, and carbonates, and make them available for plant uptake and therefore improve the growth attributes of leguminous crops [35,52]. Several previous studies have indicated that different strains of Bacillus, Pseudomonas, and Rhizobium sp. improved Zn solubilization and availability in different legumes and cereal crops [53,54]. The co-inoculation of these microorganisms with synthetic Zn fertilizers increased nutrient concentration and uptake, leading to healthy and quality grains with rich nutrient accumulation in bean cultivars [55]. The indigenous Zn solubilizing bacteria are more effective, with potentially better improvements in different phytohormones than in exogenous ones, and are able to sustainably sustain plant and grain concentrations with higher growth, yield, and soil fertility status [56]. In this way, our study also showed that shoot (Figure 3C) and grain (Table 2) Zn concentrations were improved with co-inoculation of $R$. tropici $+B$. subtilis along with $8 \mathrm{~kg} \mathrm{ha}^{-1}$ of soil applied Zn. The activities and redistribution of different Bacillus strains in rhizosphere $\mathrm{Zn}$ pools potentially increased plant $\mathrm{Zn}$ availability, growth, and assimilation to the grains of legumes and cereals, allowing them to overcome malnutrition [57].

The accumulation of $\mathrm{Zn}$ in the shoots, grains, and plants of common bean (Figure 3D-G) were improved with soil applied $\mathrm{Zn}$ and co-inoculation of $R$. tropici $+B$. subtilis bacteria. Both the accumulation and concentration of $\mathrm{Zn}$ in plant tissues are directly related to the population, availability, and composition of soil micro-biota in the root rhizosphere [58], which, therefore, with some specific strains, increased Zn availability and uptake [57]. The crops on $\mathrm{Zn}$ concentrated soils may uptake a lower concentration of $\mathrm{Zn}$ due to its oxides and carbonates [59], which should be potentially increased with root-rhizosphere $\mathrm{Zn}$ solubilizing microbes. There have been several previous studies with different crops where Bacillus strains, alone or in combination with organic and inorganic fertilizers, increased Zn availability and uptake [60,61], which, therefore, potentially combated Zn scarcity and enhanced the productivity and $\mathrm{Zn}$ accumulation in plants [62]. 
The present study also showed that soil Zn application, along with co-inoculation of R. tropici and B. subtilis, increased Zn partitioning to common bean grain in two consecutive cropping seasons (Table 3 and Figure $3 \mathrm{H}$ ). Different strains of Rhizobium sp. are one of the PGPBs that potentially convert unavailable mineral nutrients into an available form for plant uptake [63]. A previous study, with a range of bacterial isolates, indicated that Bacillus and Pseudomonas are the strains with the most potential to solubilize Zn soon after their inoculation [47,64]. Different genera of Bacillus are widely known for Zn solubilization and mobilization from soil to plant and, subsequently, to grains [34]. Therefore, our study also confirmed that $\mathrm{Zn}$ partitioning to the grains was improved with co-inoculation of R. tropici and B. subtilis. A study described that the Zn partitioning index was regulated up and down with inoculation of Bacillus in legume and cereal crops due to the up and down regulation of $\mathrm{Zn}$ transporter genes and, therefore, Bacillus is one of the most promising candidate bacteria for the bioavailability and bio-fortification in several crop [62,65].

The plant height, dry matter, and grain yield (Figure 4A-D) of common bean were also increased with soil $\mathrm{Zn}$ application and co-inoculation of diazotrophic bacteria. Zinc is one of the most imperative nutrient of its kind that affects crop growth and development [66], is known for having indispensable functions in cell division, and contains ribosomal stabilization carbohydrate and several other growth promoting enzymes. The application of $\mathrm{Zn}$ favored plant growth by favoring cell division in a better way, $\mathrm{Zn}$ being an imperative component of several plant biochemical processes [50]. Zinc has a proactive role in the maintenance of cell integrity, elongation, and multiplication [21], along with enzyme activities [22] that benefit plant physiology and biomass production with high yielding potential $[23,67]$. The present study supports these previous studies, demonstrating that, in common bean crops, the application of $\mathrm{Zn}$ resulted in taller plants with higher dry matter production and yield.

The inoculation of diazotrophic bacteria, especially Zn solubilizing bacteria, play an outstanding role in maintaining a sustainable and eco-friendly environment [28]. This micro-biota biodiversity adopts several mechanisms to not only regulate the environmental cause but also improve plant growth, physiology, and yield, with a better accumulation of nutrients in grains for human benefits $[48,64,68]$. The same strategy has been followed in our study, with soil Zn application and R. tropici and B. subtilis, for the increment of shoot dry matter, grain yield (Figure 4B-D) of common bean, and estimated Zn intake. It has been reported that Bacillus strains potentially decrease phytic-P concentration in legume grains, which improves $\mathrm{Zn}$ bioavailability in seeds for assimilation and consumption by humans, with a high feed efficiency [69]. It should also be considered that $\mathrm{Zn}$ rates tested for $\mathrm{Zn}$ concentration and intake in the present study are not of concern in term of toxicity for plants, which are recognized as being safe for common bean biofortification. This is also be due to the bio-activation of several zinc-soil-microbes-plant mechanisms to solubilize unavailable soil $\mathrm{Zn}$ and improve plant $\mathrm{Zn}$ uptake and biofortification [53,57,70]. Therefore, our results also highlight that soil Zn application has synergistically improved the nutritional status and yield of common bean when co-inoculated with $R$. tropici and B. subtilis (Table 4; Figure 4C,D).

The Zn efficiencies were improved with soil Zn application and bacterial co-inoculation (Table 5). Zinc efficiency is determined in term of $\mathrm{Zn}$ availability in the grains of low $\mathrm{Zn}$ available soils $[40,44]$. Studies determining the impact of applying $\mathrm{Zn}$ from 0 to $10 \mathrm{~kg} \mathrm{ha}^{-1}$ have demonstrated the potentially improved nutritional quality of bean grains, without toxicity symptoms, in tropical soil [71]. The sole application of Zn may lead to a negative relation with $\mathrm{Zn}$ use efficiencies [72]; however, inoculant strains of Bacillus sp. and Pseudomonas sp. are considered to have high dissolution properties regarding Zn sulphide, oxides, and carbonates [53]. These rhizosphere micro-biota adopt several mechanisms to promote the plant root system, which therefore increase nutrient uptake and utilization. Hence, our results have exhibited that $R$. tropici and B. subtilis improved ZnUE, AZnR, and $\mathrm{Zn}$ utilization (Table 5). The better $\mathrm{Zn}$ use efficiencies with $\mathrm{Zn}$ application might be due to better crop establishment and grain yield (Table 4 ), which was further increased with 
$\mathrm{Zn}$ assimilation to grains under co-inoculation of these diazotrophic bacteria (Figure $3 \mathrm{H}$ ). Our study also indicated that agro-physiological were improved with triple co-inoculation (R. tropici + A. brasilense + P. fluorescens) along with soil $\mathrm{Zn}$ application (Table 5). This positive improvement in $\mathrm{Zn}$ efficiencies with $\mathrm{Zn}$ application may be in response to the low available concentration of $Z n$ in the tropical savannah [44]. Therefore, inoculation of $\mathrm{Zn}$ solubilizing bacteria increased $\mathrm{Zn}$ partitioning and accumulation irrespective of $\mathrm{Zn}$ use efficiency and proved a sustainable and integrated strategy for grain biofortification and productivity of the common bean, the most important leguminous crop, which could improve human nutrition in a sustainable way.

\section{Conclusions}

Soil zinc application is one feasible strategy to enrich and fortify the grains of crops. The application of diazotrophic bacteria, including $\mathrm{Zn}$ solubilizing bacteria, is an interesting alternative sustainable strategy to encourage $\mathrm{Zn}$ use efficiencies in an eco-friendly way. Our results indicated that soil $\mathrm{Zn}$ application with different diazotrophic bacteria improved $\mathrm{Zn}$ concentrations in the soil, as well as in the plants and grains of common bean. It was also concluded that soil $\mathrm{Zn}$ application in combination with co-inoculation of $R$. tropici and $A$. brasilense to common bean sustainably improved $\mathrm{Zn}$-leaf. The co-inoculation of $R$. tropici and B. subtilis in combination with $\mathrm{Zn}$ better improved $\mathrm{Zn}$ concentration and accumulation in shoots and grains, with a promising effect on grain yield and the estimated $\mathrm{Zn}$ intake of the common bean. The $\mathrm{Zn}$ use efficiencies were prominently improved with co-inoculation, irrespective of $\mathrm{Zn}$ application. The $\mathrm{Zn}$ use efficiency, applied $\mathrm{Zn}$ recovery, and $Z n$ utilization efficiency were higher with co-inoculation of $R$. tropici and $B$. subtilis in comparison to all other inoculations. Therefore, co-inoculation of $R$. tropici and B. subtilis could be the most effective method, in association with soil $\mathrm{Zn}$ application, for improvement in the acquisition of plant nutrients and their use efficiencies, especially $\mathrm{Zn}$, for the better biofortification of common bean grains in tropical regions. Further studies aimed at improving Zn utilization and recovery in combination with diazotrophic bacteria and their impact on legumes biofortification, sequencing, and physiological processes should be performed under different environmental and edaphic conditions to better understand $\mathrm{Zn}$ solubilizing bacteria under field conditions.

Author Contributions: A.J. and M.C.M.T.F., conceptualized the project, investigated, collected, and analyzed the original draft of data; M.C.M.T.F., project administration and supervision; E.H.M.B., C.E.d.S.O., and F.S.G., graph editing; A.R.d.R., F.S.G., and T.A.R.N., review and editing; M.J.M.N., E.S.M., and G.C.F., field and lab help. All authors have read and agreed to the published version of the manuscript.

Funding: The authors thank the Conselho Nacional de Desenvolvimento Científico e Tecnológico (CNPq) for the productivity grant in research (award number 312359/2017-9), The World Academy of Sciences (TWAS) for the first author's scholarship (CNPq/TWAS grant number: 166331/2018-0), and the Coordenação de Aperfeiçoamento de Pessoal de Nível Superior (CAPES/AUXPE award number 88881.593505/2020-01).

Institutional Review Board Statement: Not applicable.

Informed Consent Statement: Not applicable.

Data Availability Statement: The data presented in this study are available on request from the corresponding author. The data are not publicly available due to the authors' option.

Conflicts of Interest: The authors declare no conflict of interest.

\section{References}

1. Long, J.; Zhang, J.; Zhang, X.; Wu, J.; Chen, H.; Wang, P.; Wang, Q.; Du, C. Genetic Diversity of Common Bean (Phaseolus vulgaris L.) Germplasm Resources in Chongqing, Evidenced by Morphological Characterization. Front. Genet. 2020, 11, 697. [CrossRef]

2. Hayat, I.; Ahmad, A.; Masud, T.; Ahmed, A.; Bashir, S. Nutritional and Health Perspectives of Beans (Phaseolus vulgaris L.): An Overview. Crit. Rev. Food Sci. Nutr. 2014, 54, 580-592. [CrossRef] 
3. Rivera, A.; Plans, M.; Sabaté, J.; Casañas, F.; Casals, J.; Rull, A.; Simó, J. The Spanish Core Collection of Common Beans (Phaseolus vulgaris L.): An Important Source of Variability for Breeding Chemical Composition. Front. Plant Sci. 2018, 9, 1642. [CrossRef] [PubMed]

4. Food and Agriculture Organization of the United Nations. FAOSTAT. Food and Agriculture Data; FAOSTAT: Rome, Italy, 2018.

5. Conab Follow-Up of Brazilian Grain Safra, National Supply Company. Bean Harvest-Safra 2018/19, n.7-Seventh Survey. Available online: https:/ / www.conab.gov.br/info-agro/safras/graos (accessed on 16 February 2021).

6. Soratto, R.P.; Fernandes, A.M.; Dos Santos, L.A.; Job, A.L.G. Nutrient extraction and exportation by common bean cultivars under different fertilization levels: I-macronutrients. Rev. Bras. Ciência Solo 2013, 37, 1027-1042. [CrossRef]

7. Estrada-Domínguez, V.; Sánchez-Chávez, E.; de-la-Cruz-Lázaro, E.; Márquez-Quiroz, C.; Osorio-Osorio, R. Effect of zinc chelate and sulfate on mineral content, antioxidant activity and grain yield of Vigna unguiculata L. Philipp. Agric. Sci. 2020, 103, 47-54.

8. Costa, H.; Saliba, E.; Galvani, D.; Bomfim, M.; Lana, Â.M.; Borges, A.L.; Landim, A.; Faciola, A. Effects of Zinc Sulfate or Propylene Glycol on Intake, Digestibility, and Forage Selection by Grazing Sheep in a Semi-Arid Region During the Rainy Season. Animals 2019, 9, 867. [CrossRef] [PubMed]

9. Yaseen, M.K.; Hussain, S. Zinc-biofortified wheat required only a medium rate of soil zinc application to attain the targets of zinc biofortification. Arch. Agron. Soil Sci. 2021, 67, 551-562. [CrossRef]

10. Melo, F.D.B.; Bastos, E.A.; Cardoso, M.J.; Ribeiro, V.Q. Cowpea response to phosphorus and zinc. Rev. Caatinga 2018, 31, $240-245$. [CrossRef]

11. Bhatt, R.; Hossain, A.; Sharma, P. Zinc biofortification as an innovative technology to alleviate the zinc deficiency in human health: A review. Open Agric. 2020, 5, 176-187. [CrossRef]

12. Poniedziałek, B.; Perkowska, K.; Rzymski, P. Food Fortification. Vitam. Miner. Biofortification Edible Plants 2020, 27-44. [CrossRef]

13. Maxfield, L.; Crane, J.S. Zinc Deficiency. In StatPearls [Internet]: StatPearls Publishing 2019. Available online: https://www.ncbi. nlm.nih.gov/books/NBK493231/ (accessed on 13 March 2021).

14. World Health Organization (WHO). Protein and Amino Acid Requirements in Human Nutrition: Report of a Joint FAO/WHO/UNU Expert Consultation; WHO Technical Report Series; WHO: Geneva, Switzerland, 2007; Available online: https://www.who.int/ nutrition/publications/nutrientrequirements/WHO_TRS_935/en (accessed on 16 November 2020).

15. Bollinedi, H.; Yadav, A.K.; Vinod, K.K.; Krishnan, S.G.; Bhowmick, P.K.; Nagarajan, M.; Neeraja, C.N.; Ellur, R.K.; Singh, A.K. Genome-Wide Association Study Reveals Novel Marker-Trait Associations (MTAs) Governing the Localization of Fe and Zn in the Rice Grain. Front. Genet. 2020, 11, 213. [CrossRef]

16. Gupta, S.; Kishore, A.; Alvi, M.F.; Singh, V. Designing better input support programs: Lessons from zinc subsidies in Andhra Pradesh, India. PLoS ONE 2020, 15, e0242161. [CrossRef]

17. Gammoh, N.Z.; Rink, L. Zinc in Infection and Inflammation. Nutrients 2017, 9, 624. [CrossRef] [PubMed]

18. Uwitonze, A.M.; Ojeh, N.; Murererehe, J.; Atfi, A.; Razzaque, M.S. Zinc Adequacy Is Essential for the Maintenance of Optimal Oral Health. Nutrients 2020, 12, 949. [CrossRef]

19. Skalny, A.V.; Rink, L.; Ajsuvakova, O.P.; Aschner, M.; Gritsenko, V.A.; Alekseenko, S.I.; Svistunov, A.A.; Petrakis, D.; Spandidos, D.A.; Aaseth, J.; et al. Zinc and respiratory tract infections: Perspectives for COVID-19. Int. J. Mol. Med. 2020, 46, 17-26. [CrossRef] [PubMed]

20. Kryvoruchko, I. Zn-use efficiency for optimization of symbiotic nitrogen fixation in chickpea (Cicer arietinum L.). Turk. J. Bot. 2017, 41, 423-441. Available online: https:/ /journals.tubitak.gov.tr/botany/abstract.htm?id=21254 (accessed on 13 March 2021).

21. Doolette, C.L.; Read, T.L.; Li, C.; Scheckel, K.G.; Donner, E.; Kopittke, P.M.; Schjoerring, J.K.; Lombi, E. Foliar application of zinc sulphate and zinc EDTA to wheat leaves: Differences in mobility, distribution, and speciation. J. Exp. Bot. 2018, 69, $4469-4481$. [CrossRef]

22. Rehman, A.; Farooq, M.; Asif, M.; Ozturk, L. Supra-optimal growth temperature exacerbates adverse effects of low Zn supply in wheat. J. Plant Nutr. Soil Sci. 2019, 182, 656-666. [CrossRef]

23. Ullah, A.; Farooq, M.; Nadeem, F.; Rehman, A.; Hussain, M.; Nawaz, A.; Naveed, M. Zinc Application in Combination with Zinc Solubilizing Enterobacter sp. MN17 Improved Productivity, Profitability, Zinc Efficiency, and Quality of Desi Chickpea. J. Soil Sci. Plant Nutr. 2020, 20, 2133-2144. [CrossRef]

24. Farooq, M.; Ullah, A.; Rehman, A.; Nawaz, A.; Nadeem, A.; Wakeel, A.; Nadeem, F.; Siddique, K.H. Application of zinc improves the productivity and biofortification of fine grain aromatic rice grown in dry seeded and puddled transplanted production systems. Field Crop. Res. 2018, 216, 53-62. [CrossRef]

25. Montanha, G.S.; Rodrigues, E.S.; Romeu, S.L.; De Almeida, E.; Reis, A.R.; Lavres, J.; De Carvalho, H.W.P. Zinc uptake from ZnSO 4 (aq) and Zn-EDTA (aq) and its root-to-shoot transport in soybean plants (Glycine max) probed by time-resolved in vivo X-ray spectroscopy. Plant Sci. 2020, 292, 110370. [CrossRef]

26. Haider, M.U.; Hussain, M.; Farooq, M.; Nawaz, A. Soil application of zinc improves the growth, yield and grain zinc biofortification of mungbean). J. Plant Nutr. 2018, 37, 123-128. [CrossRef]

27. Zhang, X.; Zhang, N.; Fu, H.; Chen, T.; Liu, S.; Zheng, S.; Zhang, J. Effect of zinc oxide nanoparticles on nitrogen removal, microbial activity and microbial community of CANON process in a membrane bioreactor. Bioresour. Technol. 2017, 243, 93-99. [CrossRef] [PubMed] 
28. Hakim, S.; Naqqash, T.; Nawaz, M.S.; Laraib, I.; Siddique, M.J.; Zia, R.; Mirza, M.S.; Imran, A. Rhizosphere Engineering with Plant Growth-Promoting Microorganisms for Agriculture and Ecological Sustainability. Front. Sustain. Food Syst. $2021,5,16$. [CrossRef]

29. Khoshru, B.; Mitra, D.; Khoshmanzar, E.; Myo, E.M.; Uniyal, N.; Mahakur, B.; Mohapatra, P.K.; Panneerselvam, P.; Boutaj, H.; Alizadeh, M.; et al. Current scenario and future prospects of plant growth-promoting rhizobacteria: An economic valuable resource for the agriculture revival under stressful conditions. J. Plant Nutr. 2020, 43, 3062-3092. [CrossRef]

30. Sedlakova-Kadukova, J.; Kopcakova, A.; Gresakova, L.; Godany, A.; Pristas, P. Bioaccumulation and biosorption of zinc by a novel Streptomyces K11 strain isolated from highly alkaline aluminium brown mud disposal site. Ecotoxicol. Environ. Saf. 2019, 167, 204-211. [CrossRef] [PubMed]

31. Yahaghi, Z.; Shirvani, M.; Nourbakhsh, F.; Pueyo, J. Uptake and effects of lead and zinc on alfalfa (Medicago sativa L.) seed germination and seedling growth: Role of plant growth promoting bacteria. S. Afr. J. Bot. 2019, 124, 573-582. [CrossRef]

32. Lambrese, Y.; Guiñez, M.; Calvente, V.; Sansone, G.; Cerutti, S.; Raba, J.; Sanz, M.I. Production of siderophores by the bacterium Kosakonia radicincitans and its application to control of phytopathogenic fungi. Bioresour. Technol. Rep. 2018, 3, 82-87. [CrossRef]

33. Khoshru, B.; Mitra, D.; Mahakur, B.; Sarikhani, M.R.; Mondal, R.; Verma., D.; Pant, K. Role of soil rhizobacteria in utilization of an indispensable micronutrient zinc for plant growth promotion. J. Nat. Remedies 2020, 21, 4644-4654.

34. Mumtaz, M.Z.; Ahmad, M.; Jamil, M.; Hussain, T. Zinc solubilizing Bacillus spp. potential candidates for biofortification in maize. Microbiol. Res. 2017, 202, 51-60. [CrossRef]

35. Kushwaha, P.; Srivastava, R.; Pandiyan, K.; Singh, A.; Chakdar, H.; Kashyap, P.L.; Bhardwaj, A.K.; Murugan, K.; Karthikeyan, N.; Bagul, S.Y.; et al. Enhancement in Plant Growth and Zinc Biofortification of Chickpea (Cicer arietinum L.) by Bacillus altitudinis. J. Soil Sci. Plant Nutr. 2021, 1-14. [CrossRef]

36. USDA Foreign Agriculture Services; Brazil Grain and Feed Annual. 2019. Available online: https://apps.fas.usda.gov/ newgainapi /api / report / downloadreportbyfilename?filename=Grain\%20and\%20Feed\%20Annual_Brasilia_Brazil_4-8-2019 .pdf (accessed on 15 February 2021).

37. Calegari, A.; Tiecher, T.; Hargrove, W.L.; Ralisch, R.; Tessier, D.; de Tourdonnet, S.; Guimarães, M.D.F.; dos Santos, D.R. Long-term effect of different soil management systems and winter crops on soil acidity and vertical distribution of nutrients in a Brazilian Oxisol. Soil Tillage Res. 2013, 133, 32-39. [CrossRef]

38. Raij, B.; van Andrade, J.C.; Cantarella, H.; Quaggio, J.A. Chemical Analysis for Fertility Evaluation of Tropical Soils; IAC: Campinas, Brazil, 2001; p. 285. (In Portuguese)

39. Fageria, N.K.; Baligar, V.C.; Clark, R.B. Micronutrients in crop production. Advan. Agron. 2002, 77, $185-268$.

40. Fageria, N.K.; Stone, L.F. Bean productivity in no-tillage system with application of lime and zinc. Pesqui. Agropecu. 2004, 39, 73-78. [CrossRef]

41. Malavolta, E.; Vitti, G.C.; Oliveira, S.A. Evaluation of the Nutritional Status of Plants: Principles and Applications, 2nd ed.; Potafos: Piracicaba, Brazil, 1997; p. 319. (In Portuguese)

42. Lessa, J.H.D.L.; Araujo, A.M.; Ferreira, L.A.; Júnior, E.C.D.S.; De Oliveira, C.; Corguinha, A.P.B.; Martins, F.A.D.; De Carvalho, H.W.P.; Guilherme, L.R.G.; Lopes, G. Agronomic biofortification of rice (Oryza sativa L.) with selenium and its effect on element distributions in biofortified grains. Plant Soil 2019, 444, 331-342. [CrossRef]

43. Ferreira, D.F. Sisvar: A computer statistical analysis system. Ciência Agrotecnologia 2011, 35, 1039-1042. [CrossRef]

44. Fageria, N.K.; Dos Santos, A.B.; Cobucci, T. Zinc Nutrition of Lowland Rice. Commun. Soil Sci. Plant Anal. 2011, $42,1719-1727$. [CrossRef]

45. IBGE. Directorate of Research: Coordination of Work and Income [Family Budget Survey 2017-2018: First Results]; IBGE: Rio de Janeiro, Brazil. Available online: https://agenciadenoticias.ibge.gov.br/agencia-sala-de-imprensa/2013-agencia-de-noticias/releases/ 28646-pof-2017-2018-brasileiro-ainda-mantem-dieta-a-base-de-arroz-e-feijao-mas-consumo-de-frutas-e-legumes-e-abaixodo-esperado (accessed on 24 March 2021).

46. Van Raij, B.; Cantarella, H.; Quaggio, J.A.; Furlani, A.M.C. Liming and Fertilization Recommendations for the State of São Paulo; Instituto Agronômico de Campinas: Campinas, Brazil, 1997; p. 285. (In Portuguese)

47. Rehman, A.; Farooq, M.; Naveed, M.; Ozturk, L.; Nawaz, A. Pseudomonas-aided zinc application improves the productivity and biofortification of bread wheat. Crop. Pasture Sci. 2018, 69, 659. [CrossRef]

48. Hussain, A.; Zahir, Z.A.; Asghar, H.N.; Imran, M.; Ahmad, M.; Hussain, S. Integrating the potential of Bacillus sp. Az6 and organic waste for zinc oxide bio-activation to improve growth, yield and zinc content of maize grains. Pak. J. Agric. Sci. 2020, 57, 123-130. [CrossRef]

49. Imran, M.; Arshad, A.; Khalid, S.; Kanwal, S.; Crowley, D.E. Perspectives of rhizospheremicroflora for improving Zn bioavailability and acquisition by higher plants. Int. J. Agric. Biol 2014, 16, 653-662.

50. Ullah, A.; Romdhane, L.; Rehman, A.; Farooq, M. Adequate zinc nutrition improves the tolerance against drought and heat stresses in chickpea. Plant Physiol. Biochem. 2019, 143, 11-18. [CrossRef]

51. Saini, P.; Nagpal, S.; Saini, P.; Kumar, A.; Gani, M. Microbial Mediated Zinc Solubilization in Legumes for Sustainable Agriculture. Phytomicrobiome 2021, 254-276. [CrossRef]

52. Pawar, A.; Ismail, S.; Mundhe, S.; Patil, V.D. Solubilization of insoluble zinc compounds by different microbial isolates in vitro condition. Int. J. Trop. Agric. 2015, 33, 865-869. 
53. Saravanan, V.; Madhaiyan, M.; Thangaraju, M. Solubilization of zinc compounds by the diazotrophic, plant growth promoting bacterium Gluconacetobacter diazotrophicus. Chemosphere 2007, 66, 1794-1798. [CrossRef] [PubMed]

54. Yadav, R.C.; Sharma, S.K.; Ramesh, A.; Sharma, K.; Sharma, P.K.; Varma, A. Contribution of Zinc-Solubilizing and-Mobilizing Microorganisms (ZSMM) to enhance zinc bioavailability for better soil, plant, and human health. In Rhizosphere Microbes; Springer: Singapore, 2020; pp. 357-386. [CrossRef]

55. Khande, R.; Sharma, S.K.; Ramesh, A.; Sharma, M.P. Zinc solubilizing Bacillus strains that modulate growth, yield and zinc biofortification of soybean and wheat. Rhizosphere 2017, 4, 126-138. [CrossRef]

56. Sindhu, S.S.; Sharma, R.; Sindhu, S.; Phour, M. Plant nutrient management through inoculation of zinc-solubilizing bacteria for sustainable agriculture. In Biofertilizers for Sustainable Agriculture and Environment; Giri, B., Prasad, R., Wu, Q.S., Varma, A., Eds.; Soil Biology; Springer: Cham, Switzerland, 2019; Volume 55, pp. 173-201. [CrossRef]

57. Kumar, A.; Dewangan, S.; Lawate, P.; Bahadur, I.; Prajapati, S. Zinc-Solubilizing Bacteria: A Boon for Sustainable Agriculture; Springer: Singapore, 2019; pp. 139-155. [CrossRef]

58. Ramesh, A.; Sharma, S.K.; Sharma, M.P.; Yadav, N.; Joshi, O.P. Inoculation of zinc solubilizing Bacillus aryabhattai strains for improved growth, mobilization and biofortification of zinc in soybean and wheat cultivated in Vertisols of central India. Appl. Soil Ecol. 2014, 73, 87-96. [CrossRef]

59. Rana, A.; Saharan, B.; Nain, L.; Prasanna, R.; Shivay, Y.S. Enhancing micronutrient uptake and yield of wheat through bacterial PGPR consortia. Soil Sci. Plant Nutr. 2012, 58, 573-582. [CrossRef]

60. Singh, B.; Natesan, S.K.A.; Singh, B.K.; Usha, K. Improving zinc efficiency of cereals under zinc deficiency. Curr. Sci. 2005, 36-44. Available online: https:/ / www.jstor.org/stable/24110091 (accessed on 21 March 2021).

61. Sharma, S.K.; Sharma, M.P.; Ramesh, A.; Joshi, O.P. Characterization of zinc-solubilizing Bacillus isolates and their potential to influence zinc assimilation in soybean seeds. J. Microbiol. Biotechnol. 2012, 22, 352-359. [CrossRef]

62. Goteti, P.K.; Emmanuel, L.D.A.; Desai, S.; Shaik, M.H.A. Prospective Zinc Solubilising Bacteria for Enhanced Nutrient Uptake and Growth Promotion in Maize (Zea mays L.). Int. J. Microbiol. 2013, 2013, 1-7. [CrossRef]

63. Singh, D.; Rajawat, M.V.S.; Kaushik, R.; Prasanna, R.; Saxena, A.K. Beneficial role of endophytes in biofortification of Zn in wheat genotypes varying in nutrient use efficiency grown in soils sufficient and deficient in Zn. Plant Soil 2017, 416, 107-116. [CrossRef]

64. Gontia-Mishra, I.; Sapre, S.; Tiwari, S. Zinc solubilizing bacteria from the rhizosphere of rice as prospective modulator of zinc biofortification in rice. Rhizosphere 2017, 3, 185-190. [CrossRef]

65. Khanghahi, M.Y.; Ricciuti, P.; Allegretta, I.; Terzano, R.; Crecchio, C. Solubilization of insoluble zinc compounds by zinc solubilizing bacteria (ZSB) and optimization of their growth conditions. Environ. Sci. Pollut. Res. 2018, 25, 25862-25868. [CrossRef] [PubMed]

66. Sunithakumari, K.; Devi, S.P.; Vasandha, S. Zinc solubilizing bacterial isolates from the agricultural fields of Coimbatore, Tamil Nadu, India. Curr. Sci. 2016, 25, 196-205. Available online: https:/ /www.jstor.org/stable/24906745 (accessed on 26 March 2021). [CrossRef]

67. Jalal, A.; Shah, S.; Teixeira Filho, M.C.M.; Khan, A.; Shah, T.; Hussain, Z.; Younis, M.; Ilyas, M. Yield and phenological indices of wheat as affected by exogenous fertilization of Zinc and Iron. Braz. J. Agric. Sci./Rev. Bras. Ciências Agrárias 2020, 15. [CrossRef]

68. Jalal, A.; Shah, S.; Filho, M.C.M.T.; Khan, A.; Shah, T.; Ilyas, M.; Rosa, P.A.L. Agro-Biofortification of Zinc and Iron in Wheat Grains. Gesunde Pflanz. 2020, 72, 227-236. [CrossRef]

69. Boleta, E.H.; Shintate Galindo, F.; Jalal, A.; Santini, J.M.; Rodrigues, W.L.; Lima, B.H.; Arf, O.; Silva, M.R.; Buzetti, S.; Teixeira Filho, M.C.M. Inoculation with Growth-Promoting Bacteria Azospirillum brasilense and Its Effects on Productivity and Nutritional Accumulation of Wheat Cultivars. Front. Sustain. Food Syst. 2020, 4, 265. [CrossRef]

70. Ramesh, A.; Sharma, S.K.; Joshi, O.P.; Khan, I.R. Phytase, Phosphatase Activity and P-Nutrition of Soybean as Influenced by Inoculation of Bacillus. Indian J. Microbiol. 2011, 51, 94-99. [CrossRef]

71. Vaid, S.; Kumar, B.; Sharma, A.; Shukla, A.; Srivastava, P. Effect of Zn solubilizing bacteria on growth promotion and Zn nutrition of rice. J. Soil Sci. Plant Nutr. 2014, 14, 889-910. [CrossRef]

72. Cambraia, T.L.L.; Fontes, R.L.F.; Vergütz, L.; Vieira, R.F.; Neves, J.C.L.; Corrêa Netto, P.S.; Dias, R.F.N. Agronomic biofortification of common bean grain with zinc. Pesqu. Agropecu. 2019, 54, 54. [CrossRef] 